NBER WORKING PAPER SERIES

\title{
UTILISATION OF PHYSICIAN SERVICES IN THE 50+ POPULATION. THE RELATIVE IMPORTANCE OF INDIVIDUAL VERSUS INSTITUTIONAL FACTORS IN 10 EUROPEAN COUNTRIES
}

\author{
Kristian Bolin \\ Anna Lindgren \\ Bjorn Lindgren \\ Petter Lundborg \\ Working Paper 14096 \\ http://www.nber.org/papers/w14096
}

\author{
NATIONAL BUREAU OF ECONOMIC RESEARCH \\ 1050 Massachusetts Avenue \\ Cambridge, MA 02138 \\ June 2008
}

This paper used data from the early release 1 of SHARE 2004. This release is preliminary and may contain errors that will be corrected in later releases. The SHARE data collection was preliminary funded by the European Commission through the 5th framework programme (project QLK6-CT-2001-00360 in the thematic programme Quality of Life programme area). Additional funding came from the US National Institute on Aging (U01 AG09740-13S2, P01 AG005842, P01 AG08291, P30 AG12815, Y1-AG- 4553-01 and OGHA 04-064). Data collection in Austria (through the Austrian Science Foundation, FWF), Belgium (through the Belgian Science Policy Administration) and Switzerland (through BBW/OFES/UFES) was nationally funded. Additional funding for data collection in Sweden was granted by the Swedish Council for Working Life and Social Research, the Bank of Sweden Tercentenary Foundation, and the Swedish National Board of Social Insurance. The research reported in this paper was supported by a grant from the Swedish Council for Working Life and Social Research, which is gratefully acknowledged. We are indebted to Soren Hojgard for critical remarks and helpful comments on previous drafts and to Rose-Marie Lindkvist for diligent research assistance. The views expressed herein are those of the author(s) and do not necessarily reflect the views of the National Bureau of Economic Research.

NBER working papers are circulated for discussion and comment purposes. They have not been peerreviewed or been subject to the review by the NBER Board of Directors that accompanies official NBER publications.

(C) 2008 by Kristian Bolin, Anna Lindgren, Bjorn Lindgren, and Petter Lundborg. All rights reserved. Short sections of text, not to exceed two paragraphs, may be quoted without explicit permission provided that full credit, including $(\mathrm{C}$ notice, is given to the source. 
Utilisation of Physician Services in the 50+ Population. The Relative Importance of Individual versus Institutional Factors in 10 European Countries

Kristian Bolin, Anna Lindgren, Bjorn Lindgren, and Petter Lundborg

NBER Working Paper No. 14096

June 2008

JEL No. I11

\begin{abstract}
We analysed the relative importance of individual versus institutional factors in explaining variations in the utilisation of physician services among the 50+ in ten European countries. The importance of the latter was investigated, distinguishing between organisational (explicit) and cultural (implicit) institutional factors, by analysing the influence of supply side factors, such as physician density and physician reimbursement, and demand side factors, such as co-payment and gate-keeping, while controlling for a number of individual characteristics, using cross-national individual-level data from SHARE. Individual differences in health status accounted for about 50 percent of the between-country variation in physician visits, while the organisational and cultural factors considered each account for about 15 percent of the variation. The organisational variables showed the expected signs, with higher physician density being associated with more visits and higher co-payment, gate-keeping, and salary reimbursement being associated with less visits. When analysing specialist visits separately, however, organisational and cultural factors played a greater role, each accounting for about 30 percent of the between-country variation, whereas individual health differences only accounted for 1 percent of the variation.
\end{abstract}

Kristian Bolin

Lund University Centre for Health Economics

P.O.Box 705

SE-220 07 Lund

SWEDEN

Kristian.Bolin@luche.lu.se

Anna Lindgren

Centre for Mathematical Sciences

P.O.Box 118

SE- 22100 Lund

SWEDEN

Anna.Lindgren@matstat.lu.se
Bjorn Lindgren

Lund University Centre for Health Economics

P.O. Box 705

SE-220 07 Lund

SWEDEN

and NBER

bjorn.lindgren@luche.lu.se

Petter Lundborg

Department of Economics

Free University Amsterdam

De Boelelaan 1105

NL-1081 HV Amsterdam

THE NETHERLANDS

plundborg@feweb.vu.nl 


\section{INTRODUCTION}

Healthcare utilisation rates vary considerably among the European countries (OECD 2004). The fundamental reasons for these variations still remain largely unexplored or are not yet well understood. A thorough knowledge about the determinants of healthcare utilisation seems to be crucial, though, for our ability to fruitfully confront future challenges to healthcare finance and delivery in Europe.

The utilisation of healthcare is determined by both demand and supply factors. Differences among countries might, hence, be explained both by differences in the socio-economic and demographic composition of the populations (individual factors), by differences in regulation, financing and delivery (organisational or explicit institutional factors), and by differences in traditions, norms and culture (implicit institutional factors), some affecting demand, some supply, some both demand and supply.

Due to the lack of comparable cross-national individual data, most previous comparative research on health care utilisation has been based on macro-level data. Thus, the importance of the institutional framework has certainly to some degree been illuminated, but aggregate studies are by their very nature limited in that they cannot really distinguish between the impact of individual characteristics and the impact of the institutional framework. Moreover, often these studies have analysed healthcare expenditures, whose relation to utilisation presumably differs across countries (for an overview, see Gerdtham and Jönsson, 2000).

Furthermore, the results from previous comparative macro-level research on the role of organisational factors are non-conclusive. While significant effects on healthcare expenditure have been shown for the fraction of public financing ( Leu 1986; Gerdtham et al. 1992a;) and physician supply (Gerdtham et al. 1998), no effect has apparently been shown for co-payment (Gerdtham and Jönsson 2000). Significantly lower expenditures have been reported in countries where patients 
have to pay in advance and then apply for reimbursement (Gerdtham et al. 1998). In van Doorslaer et al. (2000) and van Doorslaer et al. (2004a), physician supply or the use of a gatekeeper to specialist care did not explain country differences in healthcare utilisation at the macro level.

The purpose of this study was to analyse the relative importance of individual factors versus institutional factors in explaining variations in European outpatient healthcare utilisation, among the 50+ populations, employing comparable crossnational individual data. There are no previous studies which focus on this particular age group. Previous related evidence is limited to one study using data from the European Household Panel for 12 countries and covering the period 1994-1996 (Jiménez-Martin et al. 2002, 2004). ${ }^{1}$ Our study contributes to the limited evidence by using more recent and rich information from SHARE (Survey of Health, Ageing, and Retirement in Europe). ${ }^{2}$ The two studies had seven countries in common. While the previous study included Austria, Belgium, Denmark, Germany, Greece, Ireland, Italy, Luxembourg, the Netherlands, Portugal, Spain, and the United Kingdom, the present study did not include Belgium, Ireland, Luxembourg, Portugal and the United Kingdom, but France, Sweden and Switzerland instead.

The objective of this study and, hence, the methods applied differ from those of Jiménez-Martin et al. In this study, we compared the countries as regards to what share of the outpatient care that can be explained by different categories of variables, using estimates from a pooled sample of all countries. Thus, we implicitly assumed that the estimated coefficients were the same between countries and exploited differences in the distribution of the characteristics between the populations in order to explain differences in outpatient care utilisation. Jiménez-Martin et al., on the other hand, focused on differences between countries in the way individuals respond to the explanatory variables, and, moreover, estimated different sets of equations for men and women, respectively. The studies provide comparable estimates as regards the signs of the effects of certain explanatory variables on the utilisation of outpatient care, though. 
In order to determine the relative importance of individual-level and institutionallevel factors, we estimated the individual's healthcare utilisation assuming that it depends directly on the combination of the individual's health state and other individual characteristics, the organisational features of the healthcare systems, and implicit institutional ("cultural") factors, following a north-south gradient. We also considered GP visits and specialist visits separately, since the role of individual- and institutional factors may differ between the two types.

Several of our individual-level factors are similar to those of Jiménez-Martin et al. (2002, 2004) - health status, marital status, age, gender, education and employment, for instance - but the exact representation differs. Our study also included some life-style variables - exercise, smoking, and drinking - which were absent in their study.

In our analyses of the role of explicit institutional factors, we investigated the combined influence of four organisational characteristics of the healthcare system that may affect the utilisation of physician services. These characteristics are (1) physicians per capita, (2) gate-keeping, (3) co-payment, and (4) physician reimbursement. Jiménez-Martin et al. $(2002,2004)$ did not include co-payment but added healthcare expenditures per capita and the contribution of public expenditures to total health expenditure. First, high physician supply, indicating high access to healthcare and low transaction costs, is expected to lead to high levels of utilisation. Second, co-payment is expected to lower the level of healthcare utilisation. Third, gate-keeping is expected to reduce specialist visits and have a positive impact on GP visits. Finally, physician reimbursement by feefor-service is expected to increase the risk of over-providing, since physician incomes increase with the number of services provided. Salary payment, on the other hand, provides no such incentives.

There are other regulatory differences than the ones mentioned above among the ten countries; see Table 1. Furthermore, institutions are not only manifested in 
formal, explicit, regulatory frameworks, but also embedded in traditions, norms and culture. There are substantial differences in these respects across Europe, which may have an impact on healthcare utilisation rates in addition to individual-level and formal organisational factors. Thus, we also considered the impact of differences in implicit country-specific institutions by adding region (north, central, and south) as a marker for differences in traditions, norms and culture. ${ }^{3}$ A corresponding factor was not included in the Jiménez-Martin et al. (2002, 2004) studies.

The paper proceeds as follows. Next, the data is presented, followed by a description of the specific empirical model used in the paper. Then, the results are presented and, finally, discussed.

\section{--TABLE 1 ABOUT HERE -}

\section{data AND DESCRIPTIVES}

The SHARE database

The Survey of Health, Ageing and Retirement in Europe (SHARE) ${ }^{4}$ is a multidisciplinary and cross-national micro database, presently containing data on approximately 22000 Europeans from eleven countries. In SHARE, interviews were restricted to people aged fifty and above and their respective household members. The first wave of data was collected in 2004, containing representative samples from the non-institutionalised population in each participating country. The countries represent Northern Europe (Denmark and Sweden), Central Europe (Austria, France, Germany, Switzerland, Belgium and the Netherlands) and Southern Europe (Spain, Italy and Greece). In this paper, data from Belgium was not included, since it was not yet available. The database comprises information on health-related variables (e.g. self-reported health, physical and cognitive functioning, psychological health, well-being and life satisfaction), utilisation of healthcare (e.g. GP visits and visits to specialists), labour market variables (e.g. current work activity, job characteristics and opportunities to work past retirement age) and economic variables (e.g. sources and composition of 
current income, wealth and consumption). Additional variables include education, housing, social support variables (e.g. informal care, transfers of income and assets and social networks).

\section{Response rates}

The response rates in SHARE vary to a substantial extent between countries. The rate is lowest in Switzerland, 38 percent, and highest in France, 74 percent (Börsch-Supan and Jürges 2005). Besides France, five countries reached the 60 percent target; Germany (63\%), Denmark (63\%), Netherlands (61\%), and Greece (61\%). In addition to Switzerland, five countries failed to meet this target; Austria $(58 \%)$, Italy (55\%), Spain (53\%), and Sweden (50\%). The overall response rate in SHARE is 62 percent. This rate is comparable to the response rates obtained in two earlier European Surveys, conducted by Eurostat (the European Community Household Panel, ECHP and the European Labour Force Survey, EU-LFP). The most common reason for household non-response was refusal to participate. Whether or not there are any systematic differences between countries in the nonresponse behaviour is yet to be analysed (Börsch-Supan and Jürges 2005).

\section{-- FIGURE 1 ABOUT HERE--}

\section{Descriptives}

Figure 1 shows the average number of reported outpatient healthcare visits per person during the past twelve months for the individuals under study, divided into GP visits and visits to specialists. According to the figure, the average amount of physician visits in the SHARE samples ranged from 3 in Sweden to 9.6 in Spain.

\section{--TABLE 2 ABOUT HERE -}

Table 2 presents the variables used for the analyses, for the sample as a whole as well as for each country separately. The dependent variables measure outpatient 
healthcare utilisation (OPU), defined as the number of physician visits (total amount, GP visits and visits to specialists). The independent health variables measure the individual's health state in four dimensions. Additional, individuallevel, explanatory variables include indicators of life style, marital status, sex, age and education, among others. ${ }^{5}$ Organisational variables include physician density, gate-keeping, out-of-pocket payments, and physician reimbursement, measured at country level ${ }^{6}$. A general overview of the healthcare systems of the ten countries is given in Table 1.

As can be seen in Table 2, there were substantial differences across a number of important dimensions among individuals in the ten countries under study, which make it important to control for individual factors, when analysing the impact of differences in institutions. Regarding health, the proportion reporting bad or very bad health varied from 10 percent in Switzerland to 34 percent in Spain. These countries also had the lowest and highest mean number of chronic conditions and number of symptoms, respectively. As to education, there were wide variations. In Spain, for instance, the mean number of years of education was 5.3, whereas the corresponding figure for Germany was 13.5. Labour market participation ranged from 17 percent in Italy and Austria to 39 percent in Sweden.

Regarding life-style factors, the proportion of smokers varied from 13 percent in France to 32 percent in Denmark. The proportion of daily or almost daily alcohol consumption varied from 7 percent in Sweden to 45 percent in Italy. Similarly large variations existed in physical activity; in Spain only 36 percent engaged in some weekly sport activity, whereas the corresponding figure in Denmark and Switzerland was 60.

\section{EMPIRICAL MODEL}

In order to determine the relative importance of individual and institutional factors, we estimated the individual's healthcare utilisation assuming that it depends directly on the combination of the individual's health state and other individual characteristics, the organisation of healthcare, and the implicit 
institutional factors embodied in the traditions, norms and culture of each country. In doing so, we made the simplifying assumption that health might be regarded as an exogenous variable. ${ }^{7}$

We assumed that outpatient healthcare utilisation (OPU) follows a Poisson distribution with each individual having a separate, gamma distributed mean, giving rise to a negative binomial specification. Thus, for person $j$ residing in country $i$, we have:

$$
\operatorname{OPU}_{i j} \sim \operatorname{Poisson}\left(\mu_{i j}^{*}\right),
$$

where

$\mu_{i j}^{*}=\exp \left(\mathbf{X}_{i j} \beta_{X}+\operatorname{HEALTH}_{i j} \beta_{\text {Health }}+\operatorname{INST}_{i} \beta_{\text {Inst }}+v_{i j}\right)$,

and

$$
\exp \left(v_{i j}\right) \sim \operatorname{Gamma}(1 / \alpha, \alpha)
$$

The matrix $\mathbf{X}_{i j}$ comprises socio-economic and demographic factors, HEALTH consists of variables capturing the individual's health level and INST $_{i}$ consists of variables capturing the institutional setting in which the individual is residing.

Equation (1) was estimated in STATA employing negative binomial regression. First, estimations were made with no explanatory variables (Model 0). Second, individual characteristics were included in order to see to what extent country-specific differences in healthcare utilisation remained or changed in magnitude, first only adding health variables (Model 1), then also adding socio-economic and demographic variables (Model 2), and finally also adding life-style characteristics (Model 3). Third, institutional variables were added, first only explicit organisational features (Model 4) and then also region as a marker for implicit institutional factors (Model 5).

The unexplained between-country variation was assessed as the mean squared error (MSE) of the averaged country residuals. Thus, the average residual for country $i$ is

$$
r_{i}^{*}=\frac{1}{N_{i}} \cdot \sum_{j=1}^{N_{i}}\left(\mathrm{OPU}_{i j}-\hat{\mu}_{i j}^{*}\right)
$$

where $N_{i}$ is the number of respondents in country $i$, and

$$
\hat{\mu}_{i j}^{*}=\exp \left(\mathbf{X}_{i j} \hat{\beta}_{X}+\operatorname{HEALTH}_{i j} \hat{\beta}_{\text {Health }}+\operatorname{INST}_{i} \hat{\beta}_{\text {Inst }}\right)
$$


is the predicted number of visits, giving the MSE between countries as

$$
M S E=\frac{1}{10} \sum_{i=1}^{10}\left(r_{i}^{*}-\bar{r}\right)^{2}
$$

where $\bar{r}=\frac{1}{10} \sum_{i=1}^{10} r_{i}^{*}$ is the average of the country residuals. The MSE for Model 0 is thus a measure of the total differences between countries, while the MSEs for Models 1-5 are measures of the remaining unexplained differences, when taking account of an increasing number of individual and institutional characteristics.

The rational behind using (the change in) the mean squared error for the country mean residuals is the following: If the difference in utilisation between countries is due only to differences in the distribution of the characteristics, the average residual in each country should be zero, provided that the predictions are unbiased. If, on the other hand, there are systematic differences due to some characteristics that are not in the model, the average residuals will differ between countries. The MSE is a convenient way of quantifying this difference, since it is the sum of the variance and the square of the bias, both of which indicate a sense of miss-prediction in this context.

The relative decrease in the MSE as more characteristics are added to the model hence indicates the model's increasing ability to explain difference between the countries.

\section{RESULTS}

Regression results are presented below. For each of the outpatient care variables (total number of physician visits, total number of GP visits, total number of specialist visits) and for each of the six regression models, we present two tables, one showing mean residuals (Tables $3-5$ ), the other estimated coefficients (Tables $6-8$ ). Mean square errors of country mean residuals for each of the three outpatient care variables and for each of the six regression models are presented in Figure 2 and explained portions in Figure 3. For each of the six regression models, mean country residuals for all physician visits are shown in Figure 4, for GP visits in Figure 5, and for specialist visits in Figure 6.

\section{--TABLES 3 - 5 ABOUT HERE - -- FIGURES 2 - 6 ABOUT HERE -}


Regressions with no explanatory variables (Model 0)

First, regressions including only a constant term were run, determining the average number of total physician visits, GP visits, and specialist visits, respectively, in the material. Individual residuals were calculated, giving the mean residual for each country as well as bootstrap confidence intervals; see Tables $3-5$. The mean squared error (MSE) of these country residuals represents the between-country variation (Figure 2).

As Table 3 and Figure 4 reveal, the differences in total physician visits between countries were large, with Sweden and Spain as the two opposite extremes. A Swede had, on average, 3.3 physician visits less than expected, while a Spaniard had 3.3 visits more than expected.

Regarding GP visits, similar patterns were obtained (Table 4 and Figure 5). The difference is that Denmark had proportionally more GP visits and Germany less than expected from the total number of visits. As to specialist visits (Table 5 and Figure 6), fewer of the differences were statistically significant and only Sweden, Denmark, Germany, and Spain were significantly different from the average country.

Regressions with individual characteristics as the only explanatory variables (Models 1-3)

Model 1. Next, the regressions were re-estimated, controlling for individual health variables. It was then possible to determine to what extent differences between countries were due to differences in health status. The differences in health status explained 51 percent of the between-country variation in number of total physician visits (Table 3), 48 percent of the variation in number of GP visits (Table 4), but only 11 percent of the variation in number of specialist visits (Table 5). The large number of GP visits in Italy and Greece could, to some extent, be explained by health status but not the low number in Sweden (Table 3 and Figure 5).

Model 2. Next, we added socio-economic and demographic characteristics, which explained an additional 6 percent of the between-country variation in total physician visits (Table 3), an additional 13 percent of the variation in GP visits (Table 4), and an additional 18 percent of the variation in specialist visits (Table 5). 
Model 3. The further addition of life-style characteristics gave only marginal improvements, 3 percent, 4 percent, and 1 percent, respectively (Tables $3-5$ ).

Regressions with both individual and institutional characteristics as explanatory variables (Models 4 and 5)

Model 4. Country-specific organisational characteristics were then added. They explained an additional 15 percent of the between-country variation in physician visits (Table 3), an additional 17 percent of the variation in GP visits (Table 4), and an additional 30 percent of the variation in specialist visits (Table 5).

Model 5. Finally, region was added as a marker for unspecified, "implicit" institutional differences due to differences in traditions, norms, and culture between northern, central, and southern Europe. This made it possible to explain 91 percent of the betweencountry variation in all three variables (Tables $3-5)$.

-- TABLES 6 - 8 ABOUT HERE --

Impact of individual versus institutional factors on outpatient healthcare utilisation

Tables 6 - 8 show the effects of individual and institutional factors in the regressions of the number of total physician visits, GP visits, and specialist visits, respectively. As the models were expanded, the coefficients remained quite stable - with exceptions, though, for some life-style and institutional characteristics, when region was added in the last model. Figure 2 shows the mean squared error of the country mean residuals, decreasing as the models were expanded and more of the between-country differences were explained. Figure 3 shows the explained proportion of the MSE as the models were expanded.

Health status. Health had a large impact. As seen in Figure 3, the differences in health distribution between countries account for 50 percent of the betweencountry differences in physician and GP visits, and 10 percent of the variation in specalist visits. Being in bad or very bad health, as opposed to being in good or rather good health, increased the number of physician visits by 49 percent 
$\left(\mathrm{e}^{0.40}=1.49\right)$. Out of these, two thirds would be GP visits and one third specialist

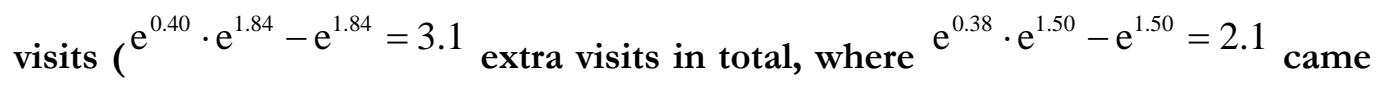
from GP visits and $\mathrm{e}^{0.40} \cdot \mathrm{e}^{0.62}-\mathrm{e}^{0.62}=1.2$ from specialist visits). An increase in the number of chronic conditions by one was associated with a 20 percent increase in both GP and specialist visits. An increase by one activity limitation was associated with an 8 percent increase in number of GP visits and a 5 percent increase in specialist visits while the percentages were reversed for an increase of one additional symptom.

Socio-economic and demographic characteristics. When taking the effect of health differences into account, the socio-economic and demographic differences between countries had a smaller impact on the between-country differences in physician visits (less than 10 percent), somewhat larger on the GP visits (more than 10 percent), while explaining an additional 20 percent of the differences in specialist visits. Women had significantly more physician and GP visits and considerably more specialist visits than men. The increase in number of visits with age is, however, significantly smaller for women than for men. Being widowed increased the number of GP visits, especially for women, but decreased the number of specialist visits for men and increased it for women. The net effect on total physician visits was a significant increase for widowed women, but not for men. Education had a significant negative effect on GP visits, but a significant positive effect on specialist visits. These effects were rather small, however. The effect of education on the total amount of physician visits was insignificant, suggesting that the effects on GP and specialist visits cancelled each other out. Being employed decreased the amount of visits by 15-25 percent, while being born in the country had a small or non-significant negative effect on the number of visits.

Life style. As to life-style factors, they made a very small contribution towards explaining the between-country differences, explaining, at most, an additional 5 percent. It can be noted that both smoking and drinking alcohol daily were associated with a significantly lower amount of physician visits. Being a former smoker, however, was associated with a significantly higher number of specialist visits. Physical activity was associated with a smaller number of GP visits but had very little effect on specialist visits. 
Organisational features. Differences in organisational features between countries were the most important factor for the variation in specialist visits, explaining an additional 30 percent of the between-country differences. It also explained 20 percent of the differences in GP visits and 15 percent of the differences in total physician visits. A larger physician supply had a large positive effect on the number of both GP and specialist visits. Access restriction to specialists had a positive effect on the number of GP visits and a smaller and negative effect on the number of specialist visits. Out-ofpocket payment was associated with fewer visits of both kinds, while salary-based provider payment decreased the number of GP visits, but not the number of specialist visits.

Region. Organisational features are highly associated with the traditions, norms and culture of a country. The region dummies explained another 30 percent of the differences in specialist visits, less than 10 percent of the GP visits and 15 percent of the physician visits. Thus, when region was added, only the effect of access restriction remained unchanged, while the effects of physician supply and out-of-pocket payment were substantially reduced. The effect of salary-based payment became non-significant for GP visits but increased for specialist visits. Denmark and Sweden still had a significantly lower number of visits of all kinds than the other countries, while Greece, Italy, and Spain had a somewhat lower number of specialist visits.

In sum. Health status was by far the most important individual-level determinant, explaining half of the between-country variation in GP visits. Factors such as education and employment status were certainly significant, but they did not contribute much in explaining country differences in healthcare utilisation. Organisational differences contributed less than health but somewhat more than other individual characteristics in explaining country differences in total physician and GP visits. Organisational differences explained as much of the differences in specialist visits as the individual characteristics did. All the characteristics together managed to explain nearly all (90 percent) of the differences between countries. 


\section{DISCUSSION}

The objective of this study was to analyse the relative importance of individual versus institutional factors in explaining differences in the utilisation of physician services among the $50+$ in Europe. Previous cross-country macro-level comparisons have in general been concerned with determinants for healthcare expenditures, while healthcare utilisation for the most part has been handled in single-country individual-level studies, where the effects of institutional factors cannot be identified. The exception is the comparative study by Jiménez-Martin et al. (2002, 2004), using data from the European Community Household Panel.

The recently developed SHARE data offers another and an exceptionally good basis for comparative analyses of healthcare utilisation. We used the first wave of the collection of SHARE data for our analyses. The main differences between the European Community Household Panel and the SHARE survey are (1) that the SHARE survey was developed especially for the purpose of analysing those $\mathbf{5 0}$ years of age and older, and (2) that the SHARE survey contains more elaborate health-related information. Obviously, it is also the case that the SHARE data contains more recent information and, hence, reflects recent-date facts and circumstances not covered by the European Community Household Panel.

According to our results, individual differences in health were the main driver of between-country variation in physician visits, explaining about 50 percent of the variation. Our organisational variables, i.e., physician density, co-payment, gatekeeping, and physician reimbursement, explained an additional 15 percent of the between-country variation. Interestingly, demographic, socio-economic, and lifestyle factors added only little, about 10 percent, in explaining the country differences in physician visits.

A somewhat different picture emerged, when GP visits and specialist visits were analysed separately. While individual differences in health accounted for 51 percent of between-country variation in GP visits, they only accounted for 11 percent of the variation in specialist visits. In the latter case, institutional factors 
played a greater role, accounting for 30 percent of the between-country variation in specialist visits. Moreover, socio-economic, demographic, and lifestyle factors played a more important role here, explaining an additional 19 percent of the between-country variation.

Our organisational variables showed the expected signs, with higher physician density being associated with more visits, whereas co-payment, gate-keeping, and salary reimbursement were associated with less visits. It should be noted that certain institutional factors are highly associated with certain regions. The lowest physician density, for instance, was found in Denmark and Sweden, meaning that this variable may pick up other unobserved characteristics of this region as well. If these unobserved factors, for instance, traditions, norms and culture were associated with both a low physician density and a low number of visits, the former variable would be endogenous and the result should be interpreted with care. For other organisational variables considered, there seemed to be less of an association with a certain region.

In order to be able to incorporate organisational variables into the empirical analysis, certain simplifications were necessary. Mixed systems, large variations and numerous exemptions within a country are all circumstances that aggravate the possibilities for specifying the effects on utilisation more precisely. This may also explain why our categorisation differs from that used by Jiménez-Martin et al. (2002, 2004). Based on Stepan and Sommersguter-Reichmann (2005), we concluded that there was a gate-keeper function in Austria, while Jiménez-Martin et al. $(2002,2004)$ did not identify such a restriction of access to specialist care. On the other hand, Jiménez-Martin et al. (2002, 2004) identified a gate-keeper function in the Netherlands, while we did not, based on Schut and van de Ven (2005). Based on Mossialos et al. (2005), we concluded that the provision of physician visits in Greece was mainly non-salaried, while Jiménez-Martin et al. $(2002,2004)$ reported salary as the major form of payment for physician visits. It should be observed that in most of the ten countries, hospital specialists are paid by salary, whereas GPs, primary-care physicians, and specialists in outpatient care are paid by capitation and/or on a fee-for-service basis (Table 1). Furthermore, the mix between salaried and non-salaried payments may have changed between the study years, 1994-1996 for Jiménez-Martin et al. (2002, 2004) 
and 2004 for the present study, since reforms have been going on in Europe for quite some time Oliver et al. (2005).

The results obtained in this study pertains to individual healthcare utilisation of those 50 years of age and older, while the results presented by Jiménez-Martin et al. $(2002,2004)$ were obtained using data on a population that was on average about 40 years of age. The demand for health and health investments differs between age groups, suggesting that our results are principally different from those obtained by Jiménez-Martin et al. There are no theoretical reasons, however, for believing that the effects of the included explanatory variables would be qualitatively different between age groups, only that the quantitative effects are. Thus, both studies found (1) that chronic illness was associated with more GP visits; (2) education with less GP visits; and (3) being employed with less GP visits (none of the Jiménz-Martin estimates were significant, however,and in one of the equations, the reverse effect was obtained for women). Age was linearly associated with more GP visits in this study, while Jiménez-Martin et al. found that age was associated with less visits, but this association diminished with age.

The comparisons between the studies as regards the results from the specialistvisits regressions yielded the same conclusions as with GP visits, regarding chronic illness, and being employed, respectively. Further, we found a positive association between education and specialist visits, as did the results from the female sample in the Jiménez-Martin study, whereas the male sample showed the reverse association. While Jiménez-Martin et al. found a diminishing negative association between age and the number of specialist visits for the female sample and no significant results for men, this study found a positive association.

The most noteworthy difference between the results above is the difference as regards the association between age and GP and specialist visits, respectively. One plausible explanation for these differences is the difference in age composition of the two samples employed. More specifically, a possible mechanism that can explain why the utilisation of specialist visits decreases with 
age in the Jiménez-Martin et al. studies is that specialist visits related to child bearing were present in their sample but not in ours.

Among the organisational variables, both studies found a positive association between access restrictions to specialists and GP visits and a negative association between access restrictions and specialist visits, i.e. results which are in accordance with expectations. However, whereas we found the expected positive associations between physician supply and GP- and specialist visits, respectively, the Jiménez-Martin et al. study obtained a negative association between physician supply and specialist visits. Finally, there was a negative association between salary payment and GP visits, which is in accordance with expectations, and a positive association between salary payment and specialist visits in our study, opposite to the findings of Jiménez-Martin et al. Other organisational variables were not comparable between the two studies.

Even though the signs of parameter values were the same for some organisational variables, there are also some important differences. Overall, the results of this study seem to be more in accordance with predictions or expectations than those of Jiménez-Martin et al. study. There might certainly be real explanations due to differences in health and health-related behaviour, for instance,making GP- and specialist visits complements for older individuals, and substitutes for the younger individuals. This is a mere speculation, though, since differences in results also might be due to differences in definitions or measurement of variables. This is rather obvious, when one looks at the results regarding the effect of salary payment. Since specialists as a rule are salaried in all the countries in our study, the organisational variable salary payment reflects variations in payment system for the GPs only. It is also a variable where our categorisation differs from Jiménez-Martin et al.'s.

A few more caveats may be in order. First, even though the SHARE data is certainly unique in content and scope, many simplifications had to be made in order to produce a workable survey questionnaire. This fact also had consequences for this study, the most important one being that the physician visit 
was treated as a homogeneous service, even though its content, length and quality may differ both within and across countries. SHARE data certainly distinguishes between GP visits and specialist visits, but the degree to which a GP is "specialised" may differ. In the Netherlands, for instance, GPs are specialised in some common diseases in order to keep the referral rate low (Exter et al. 2004). Consequently, some of what in most countries would be denoted 'specialist services' are in the Dutch case provided by GPs.

The quality of a physician visit appears to depend largely on the organisational structure (Potter and McKinlay 2005). Patient satisfaction is one element in the concept of quality. One study (Larsson et al. 2005) found that patients in France and England were generally more satisfied with healthcare than patients in Norway and Sweden, possibly because of higher levels of information and the existence of family physicians, signifying a closer relationship between patient and practitioner. Higher quality in terms of less prescriptions of drugs, more health promotion and better outcomes has been found to be positively related to the length of the consultation (Freeman et al. 2002; Wilson and Childs 2002). A study on consultation length in six European countries showed that longer visits tended to include more information to the patient and a higher degree of psychosocial talk (Deveugele et al. 2004).

The average length of a physician visit differs widely across countries. While Germany and Spain have quite short visits of around seven to eight minutes, visits in Switzerland tend to last longer than fifteen minutes. (Deveugele et al. 2002) Interestingly, the number of visits and the average consultation length appear to match. Spain, which had most visits per person after controlling for individual characteristics, has, as already mentioned, very short visits, while visits in Sweden, which had the lowest number of visits per person, are of at least the double length (Andersson and Mattsson 1989). 
In the face of former research on healthcare utilisation, the absence of at least two independent variables in our estimations requires justification. Although income has been shown to affect healthcare utilisation (Kephart et al. 1998; Rohrer and Culica 1999; van Doorslaer et al. 2000), it was not included here. In the survey, only gross income was asked for. Since the tax and welfare systems of the participating countries vary to a great extent, as is evident from table 9, it was not possible to calculate net income in the present context. Income is, however, to some extent captured in the variables indicating education and employment status. Nor was the patient's time and travel costs when visiting a physician included, even though these appear to affect healthcare utilisation (Chiappori et al. 1998; Riphahn et al. 2003). In SHARE, no satisfactory indicator of these costs was available. The degree of urbanisation, as a possible indicator ${ }^{8}$, was reported in SHARE but has shown little effect on healthcare utilisation (van Doorslaer et al. 2004a). Moreover, the frequency of, for instance, physician home visits, which give rise to particularly low time and travel costs and which differ widely across countries, depend more on institutional factors. ${ }^{9}$

The above mentioned limitations and special circumstances are caveats that need to be considered, while interpreting the estimation results. However, the shortcomings should be redeemed by the high quality of the data in general, one of its strong points being the numerous dimensions of health, measured objectively as well as subjectively. This was the more important, since the variables measuring health proved to be the most determining for utilisation among the individual factors.

The main finding of this paper was that individual differences in health accounted for the major part of the between-country variation in physician visits. Organisational factors played a less important role, accounting for about 15 percent of the variation. This suggests that changes in the organisational framework might affect utilisation patterns, but only to a limited extent. However, the complexity of healthcare systems and the heterogeneous nature of physician visits call for deeper analysis before tangible policy recommendations to increase efficiency and quality of healthcare can be produced. 
NOTES 


\section{REFERENCES}

Andersson, SO and B Mattsson (1989), "Length of consultations in general practice in Sweden: views of doctors and patients.," Family Practice, 6, 130-34.

Anell, A. (2005), "Swedish healthcare under pressure," Health Economics, 14, 237-54.

Bago d'Uva, T. (2005). "Latent class models for utilisation of primary care: evidence from a British panel," Health Economics, 14, 873-892.

Becker, Gary (1964), Human Capital. Chicago: The University of Chicago Press.

Bellanger, M. M. and P. R. Mossé (2005), "The search for the Holy Grail: combining decentralised planning and contracting mechanisms in the French health care system.," Health Economics, 14, 119-32.

Bergeron, R., A. Laberge, and L. Vezina (1999), "Which physicians make home visits and why? A survey.," Canadian Medical Association Journal, 161 (4), 369-74.

Bolin, K., B. Lindgren, and P. Lundborg (2008), "Informal and formal care among singleliving elderly in Europe", Health Economics, 17 (3), 393-410.

Bolin, K., B. Lindgren, and P. Lundborg (2008), " Your next of kin or your own career? Caring and working among the 50+ of Europe", Journal of Health Economics. (in press). Available on Publisher's Website.

Börsch-Supan, A., A. Brugiavini, H. Jürges, J. Mackenbach, J. Siegrist, and G. Weber Eds. (2005), Health, Ageing and Retirement in Europe. First results from the Survey of 
Health, Ageing and Retirement in Europe. Mannheim: Research Institute for the Economics of Aging..

Börsch-Supan, A. and H. Jürges Eds. (2005), The Survey of Health, Ageing and Retirement in Europe - Methodology. Mannheim: MEA.

Chiappori, P-A., F. Durand, and P-Y. Geoffard (1998), "Moral hazard and the demand for physician services: first lessons from a French natural experiment.," European Economic Review, 42, 499-511.

Daatland, S.O. and K. Herlofson (2003), "Lost solidarity" or "changed solidarity": a comparative European view of normative family solidarity, Ageing and Society 23, 537560.

Deveugele, M, A Derese, D De Bacquer, A van den Brink-Muinen, and J De Maeseneer (2004), "Consultation in general practice: a standard operating procedure?," Patient Education and Counseling, 54 (2), 227-33.

Deveugele, M, A Derese, A van den Brink-Muinen, J Bensing, and J De Maeseneer (2002), "Consultation length in general practice: cross sectional study in six European countries.," British Medical Journal, 325, 472.

Exter, A., H. Hermans, M. Dosljak, and R. Busse (2004), Health care systems in transition: Netherlands. Copenhagen: WHO Regional Office for Europe on behalf of the European Observatory on Health systems and Policies.

France, G., F. Taroni, and A. Donatini (2005), "The Italian health-care system.," Health Economics, 14, 187-202. 
Freeman, G.K., J.P. Horder, J.G.R. Howie, A.P. Hungin, A.P. Hill, N.C. Shah, and A. Wilson (2002), "Evolving general practice consultation in Britain: issues of length and context.," British Medical Journal, 324, 880-82.

Freeman, R. (2000), The Politics of Health in Europe. Manchester: Manchester University Press.

Gerdtham, U-G. and B. Jönsson (2000), "International comparisons of health expenditure". In Culyer, A.J. and J.P Newhouse (eds), Handbook of Health Economics. Amsterdam: Elsevier, 11-54.

Gerdtham, U-G., B. Jönsson, M. MacFarlan, and H. Oxley (1998), "The determinants of health expenditure in the OECD countries.," in Health, The Medical Profession, and Regulation., P. Zweifel, Ed. Dordrecht: Kluwer Academic Publishers.

Gerdtham, U-G., J. Sögaard, F. Andersson, and B. Jönsson (1992a), "Econometric analysis of health care expenditures: a cross-section study of the OECD countries.," Journal of Health Economics, 11, 63-84.

Grossman, M. (1972a), The Demand for Health: A Theoretical and Empirical Investigation. New York: Columbia University Press for the National Bureau of Economic Research.

---- (1972b), "On the concept of health capital and the demand for health.," Journal of Political Economy, 80, 223-55.

Jiménez-Martin S, Labeaga JM, Martínez-Granado M. (2002). Latent class versus twopart models in the demand for physician services across the European Union. Health Economics 11, 301-321. 
Jiménez-Martin S, Labeaga JM, Martínez-Granado M. (2004). An empirical analysis of the demand for physician services across the European Union. European Journal of Health Economics 5, 150-165.

Kephart, G., V. S. Thomas, and D. R. MacLean (1998), "Socioeconomic differences in the use of physician services in Nova Scotia.," American Journal of Public Health, 88, 800-04.

Kohli, M., H. Künemund, J. Lüdicke (2005), "Family structure, proximity and contact", In Börsch- Supan A., A. Brugiviani, H. Jürges, J. Mackenbach, J. Siegrist, and G. Weber (eds) Health, Ageing, and Retirement in Europe. First results from the Survey of Health, Ageing and Retirement in Europe. Mannheim: Research Institute for the Economics of Aging.

Lancaster, Kelvin J. (1966), "A new approach to consumer theory," The Journal of Political Economy, 74 (2), 132-57.

Larsson, Bodil Wilde, Gerry Larsson, Marie Wickman Chantereau, and Karin Stael von Holstein (2005), "International comparisons of patients' views on quality of care.," International Journal of Health Care Quality Assurance, 18 (1), 62-73.

Leu, R. E. (1986), "The public-private mix and international health care costs.," in Public and Private Health Services, A. J. Culyer and B. Jönsson, Eds. Oxford: Basil Blackwell.

Lopez-Casanovas, G., J. Costa-Font, and I. Planas (2005), "Diversity and regional inequalities in the Spanish 'system of health care services'." Health Economics, 14, 221 35.

Mossialos, E., S. Allin, and K. Davaki (2005), "Analysing the Greek health system: a tale of fragmentation and inertia.," Health Economics, 14, 151-68. 
OECD (2004), "OECD Health Data 2004. A comparative analysis of 30 countries.," OECD Health Data.

---- (2003), "OECD Health Data: Statistics and indicators for 30 countries.," See the web page: http://www.oecd.org/dataoecd/59/47/35529872.xls. (29.11.2005).

Potter, S. J. and J. B. McKinlay (2005), "From a relationship to encounter: an examination of longitudinal and lateral dimensions in the doctor-patient relationship.," Social Science and Medicine, 61 (2), 465-79.

Reher, DS. (1998), "Family ties in western Europe: persistent contrasts", Population and Development Review, 24, 203-234.

Riphahn, R. T., A. Wamback, and A. Million (2003), "Incentive effects in the demand for health care: a bivariate panel count data estimation.," Journal of Applied Econometrics, $18,387-405$.

Rohrer, J. E. and D. V. Culica (1999), "Identifying high-users of medical care in a farming-dependant county.," Health Care Management Review, 24, 28-34.

SHO (2003), "Panorama Gesundheit - die Schweiz im europäischen Vergleich.," Swiss Health Observatory, WHO.

Stepan, A. and M. Sommersguter-Reichmann (2005), "Monitoring political decisionmaking and its impact in Austria.," Health Economics, 14, 7-23. 
van Doorslaer, E., C. Masseria, and the OECD health Equity Research Group Members (2004a), "Income-related inequality in the use of medical care in 21 OECD countries.," in OECD Health Working Papers No. 14.

van Doorslaer, E., A. Wagstaff, H. van der Burg, T. Christiansen, D. De Graeve, I. Duchesne, U-G. Gerdtham, M. Gerfin, J. Geurts, U. Hakkinen, J. John, J. Klavus, R. E. Leu, B. Nolan, O. O'Donnell, C. Propper, F. Puffer, M. Schellhorn, G. Sundberg, and O. Winkelhake (2000), "Equity in the delivery of health care in Europe and the US.," Journal of Health Economics, 19, 553-83.

van Doorslaer, E., Koolman, X., Jones, A. (2004b). Explaining income-related inequalities in doctor utilisation in Europe. Health Economics, 13, 629-647.

van Doorslaer, E., Koolman, X., Puffer, F. Equity in the Use of Physician Visits in OECD Countries: has equal treatment for equal need been achieved?. Measuring Up: Improving Health Systems Performance in OECD Countries. OECD, Paris, 2002, pp. 25-248.

Wilson, A and S Childs (2002), "The relationship between consultation length, process and outcomes in general practice: a systematic review.," British Journal of General Practice, 52 (485), 1012-20.

Wörz, M. and R. Busse (2005), "Analysing the impact of health care system change in the EU member states - Germany.," Health Economics, 14, 133-49.

Zweifel, P. and F. Breyer (1997), Health Economics. New York: Oxford University Press.

\footnotetext{
* Corresponding author. Address for correspondence: Lund University Centre for Health Economics (LUCHE), P.O. Box 705, SE-220 07 Lund, Sweden. Tel: +46 4622206 56. Fax: +46 4622206 51. E-mail: Kristian.Bolin@nek.lu.se; Kristian.Bolin@luche.lu.se. This paper used data from the early release 1 of
} 
SHARE 2004. This release is preliminary and may contain errors that will be corrected in later releases. The SHARE data collection was preliminary funded by the European Commission through the $5^{\text {th }}$ framework programme (project QLK6CT-2001-00360 in the thematic programme Quality of Life programme area). Additional funding came from the US National Institute on Aging (U01 AG0974013S2, P01 AG005842, P01 AG08291, P30 AG12815, Y1-AG- 4553-01 and OGHA 04064). Data collection in Austria (through the Austrian Science Foundation, FWF), Belgium (through the Belgian Science Policy Administration) and Switzerland (through BBW/OFES/UFES) was nationally funded. Additional funding for data collection in Sweden was granted by the Swedish Council for Working Life and Social Research, the Bank of Sweden Tercentenary Foundation, and the Swedish National Board of Social Insurance. The research reported in this paper was supported by a grant from the Swedish Council for Working Life and Social Research, which is gratefully acknowledged. We are indebted to Sören Höjgård for critical remarks and helpful comments on previous drafts and to Rose-Marie Lindkvist for diligent research assistance.

${ }^{1}$ An additional number of papers use the same data to study the demand for physician visits in Europe, but do not explicitly consider the role of institutional factors (Bago d'Uva 2006); van Doorslaer et al. 2002; van Doorslaer et al. 2004b).

${ }^{2}$ See the web page: http://www.share-project.org/, and the next section regarding data.

${ }^{3}$ The north-south gradient in traditions, norms and culture has been emphasized by several authors, for instance, Reher (1998), Freeman (2000), Daatland and Herlofson (2003), Kohli et al. (2005), and Bolin et al. (2008a,b).

${ }^{4}$ SHARE follows the design of the US Health and Retirement Study (HRS, web page: http://hrsonline.isr.umich.edu/) and the English Longitudinal Study of Ageing (ELSA, web page: http://www.ifs.org.uk/elsa/). The SHARE data set is introduced in Börsch-Supan, Brugiavini et al (2005). Methodological details can be found in Börsch-Supan and Jürges (2005).

\footnotetext{
${ }^{5}$ We note that the lifestyle variables are potentially endogenous. Their coefficients should therefore be interpreted with some caution.
} 
${ }^{6}$ Since specialists as a rule are salaried in all the countries in our study (Table 1), the organisational variable salary payment, measured at country level, here reflects variations in payment system for the GPs only.

${ }^{7}$ According to neoclassical theory before the beginning of the 1960s, the individual derives utility directly from market goods and services. Lancaster (1966), in his new approach to consumer theory, asserted that consumers utilise market goods and services in a process of production and consumption, and that the outcomes of such processes (commodities) are the fundamental objects of choice. It follows from Lancaster's approach that the demand for market goods and services is derived from (1) the individual's demand for commodities (preferences), and (2) the individual's capability of transforming market goods and services into commodities (technology). Building on human capital theory (Becker 1964), and Lancaster's insights Grossman (1972a, b) emphasised that health is a durable capital stock and that it differs from, for instance, educational capital in that its main influence is on the individual's time-budget constraint better health means more time available that can be freely allocated to various purposes by the individual. Grossman showed that this approach has important implications for understanding individual health-related behaviour. For our purposes, however, it suffices to assume that health is exogenously given..

${ }^{8}$ People living in urban areas would generally have higher access to physicians and consequently lower time and travel costs compared to people living in rural areas.

${ }^{9}$ Private practicing physicians tend to have a much higher level of physician home visits compared to publicly employed physicians (Bergeron et al. 1999). Thus, in countries where most physicians are publicly employed, the amount of home visits ought to be comparatively lower.

${ }^{6}$ Sources: AT: (Stepan and Sommersguter-Reichmann 2005) CH: (SHO 2003) DE: (Wörz and Busse 2005) DK: ES: (Lopez-Casanovas et al. 2005) FR: (Bellanger and Mossé 2005) GR: (Mossialos et al. 2005) IT: (France et al. 2005) NL: (Exter et al. 2004) SE: (Anell 2005) Figures on physician supply: (OECD 2003). 
Table 1. Overview of the organisational structure of outpatient healthcare in ten European countries ${ }^{6}$

\begin{tabular}{|c|c|c|c|c|c|c|c|}
\hline & $\begin{array}{l}\text { Healthcare } \\
\text { System }\end{array}$ & $\begin{array}{l}\text { Patient contributions } \\
\text { Indirect }\end{array}$ & Direct & Provider payment & $\begin{array}{l}\text { Physician } \\
\text { supply/1000 }\end{array}$ & $\begin{array}{l}\text { Physician } \\
\text { distribution }\end{array}$ & $\begin{array}{l}\text { Access restrictions } \\
\text { to specialist care. }\end{array}$ \\
\hline AT & $\begin{array}{l}\text { Social insurance } \\
\text { decentralized }\end{array}$ & $\begin{array}{l}\text { Compulsory on } \\
\text { income }\end{array}$ & $\begin{array}{l}\text { Only to non-contracted } \\
\text { physicians: } 20 \%\end{array}$ & $\begin{array}{l}\text { Flat rate per basic treatment }+ \text { FFS } \\
\text { Hospital specialists: salary }\end{array}$ & $3.4(2003)$ & $\begin{array}{l}\text { Regulated, also } \\
\text { in number }\end{array}$ & Yes \\
\hline $\mathrm{CH}$ & $\begin{array}{l}\text { Privately } \\
\text { financed } \\
\text { decentralized }\end{array}$ & $\begin{array}{l}\text { Compulsory, same } \\
\text { level for all }\end{array}$ & $\begin{array}{l}230 \mathrm{CHF}+10 \% \text {, capped at } 600 \\
\text { CHF per year }\end{array}$ & $\begin{array}{l}\text { FFS. } \\
\text { Hospital specialists: salary }\end{array}$ & $3.6(2003)$ & $\begin{array}{l}\text { Regulation in } \\
\text { number }\end{array}$ & No \\
\hline $\mathrm{DE}$ & Social insurance & $\begin{array}{l}\text { Compulsory on } \\
\text { income under a } \\
\text { certain level }\end{array}$ & $\begin{array}{l}€ 10 \text { per quarter/at least } 2 \% \text { of } \\
\text { gross income per year }\end{array}$ & Limited 2-step FFS, set ex post & $3.4(2004)$ & $\begin{array}{l}\text { Regulated, also } \\
\text { in number }\end{array}$ & No \\
\hline DK & $\begin{array}{l}\text { Tax financed } \\
\text { decentralized }\end{array}$ & $\begin{array}{l}\text { Tax on income and } \\
\text { property }\end{array}$ & No & $\begin{array}{l}\text { Capitation }(1 / 3)+\text { FFS }(2 / 3) \\
\text { Hospital specialists: salary }\end{array}$ & $2.8(2003)$ & No regulation & Yes \\
\hline ES & $\begin{array}{l}\text { Tax financed } \\
\text { decentralized }\end{array}$ & $\begin{array}{l}\text { Tax: income, } \\
\text { consumption }\end{array}$ & No & $\begin{array}{l}\text { Salary + variable part } \\
\text { Some services: capitation }\end{array}$ & $3.2(2003)$ & No regulation & Yes \\
\hline FR & Social insurance & $\begin{array}{l}\text { Compulsory on } \\
\text { income }\end{array}$ & $\begin{array}{l}€ 1 \text { per service }+30 \%, 86 \% \\
\text { have insurance for the } 30 \%\end{array}$ & $\begin{array}{l}\text { I: fixed FFS. II: FFS, unfixed, } 15 / 38 \% \text { of the cost } \\
\text { per GP/specialist visit }\end{array}$ & $3.4(2003)$ & $\begin{array}{l}\text { Regulated in } \\
\text { number only }\end{array}$ & $\begin{array}{l}\text { Yes } \\
\text { (weak) }\end{array}$ \\
\hline GR & Tax financed & $\begin{array}{l}\text { Compulsory for } \\
\text { employed }\end{array}$ & $\begin{array}{l}\text { First contact is free. } \\
\text { (Informal payments?) }\end{array}$ & $\begin{array}{l}\text { Capitation, FFS, and informal payments } \\
\text { Hospital specialists: Salary }\end{array}$ & $\begin{array}{l}4.4(2003)(98 \% \\
\text { specialists) }\end{array}$ & No regulation & No \\
\hline IT & $\begin{array}{l}\text { Tax financed } \\
\text { decentralized }\end{array}$ & $\begin{array}{l}\text { Taxes; income, } \\
\text { business, VAT }\end{array}$ & $\begin{array}{l}\text { Cap of } € 35 \text { per service category } \\
\text { (many exemptions) }\end{array}$ & Unadjusted capitation, salary & $4.1(2003)$ & $\begin{array}{l}\text { Regulated, also } \\
\text { in number }\end{array}$ & $\begin{array}{l}\text { Yes } \\
\text { (weak) }\end{array}$ \\
\hline NL & $\begin{array}{l}\text { Social insurance } \\
\text { decentralized }\end{array}$ & $\begin{array}{l}\text { Tax rate + flat rate } \\
\text { (compulsory under a } \\
\text { certain income level) }\end{array}$ & No & $\begin{array}{l}\text { Capitation or FFS } \\
\text { Hospital specialists: Salary }\end{array}$ & $3.1(2003)$ & $\begin{array}{l}\text { Regulated in } \\
\text { number }\end{array}$ & No \\
\hline SE & $\begin{array}{l}\text { Tax financed } \\
\text { decentralized }\end{array}$ & Tax on income & $\begin{array}{l}\text { Around } € 11 \text { per visit, capped at } \\
€ 100 \text { per year }\end{array}$ & Salary & $3.3(2003)$ & $\begin{array}{l}\text { Regulated in } \\
\text { number }\end{array}$ & No \\
\hline
\end{tabular}


Table 2: Descriptive statistics

\begin{tabular}{|c|c|c|c|c|c|c|c|c|c|c|c|c|c|}
\hline \multirow[t]{2}{*}{ Variables } & & Variable description & All & $\mathrm{AT}$ & $\mathrm{CH}$ & $\mathrm{DE}$ & DK & ES & FR & GR & $\mathrm{IT}$ & NL & SE \\
\hline & & Number of persons & 19072 & 1882 & 892 & 2898 & 1505 & 1755 & 1421 & 1903 & 2311 & 2611 & 1894 \\
\hline \multicolumn{14}{|l|}{ Endogenous } \\
\hline \multirow[t]{3}{*}{ OPU } & timesdoctor & $\begin{array}{l}\text { Number of visits to a physician past } 12 \text { months (dentist visits and } \\
\text { hospital stays excluded, but emergency room or outpatient clinic } \\
\text { visits included) }\end{array}$ & 6.35 & 6.51 & 4.67 & 7.70 & 4.34 & 9.63 & 7.36 & 5.54 & 8.78 & 4.56 & 3.00 \\
\hline & timesGP & Number of GP visits past 12 months & 4.49 & 4.81 & 3.14 & 4.97 & 3.28 & 7.48 & 5.49 & 3.71 & 6.85 & 2.73 & 1.80 \\
\hline & timesspec & Number of specialist visits past 12 months & 1.86 & 1.70 & 1.53 & 2.73 & 1.06 & 2.14 & 1.87 & 1.84 & 1.93 & 1.83 & 1.20 \\
\hline \multicolumn{14}{|l|}{ Exogenous } \\
\hline \multirow[t]{4}{*}{ Health status } & chronic & Number of chronic conditions out of 14 listed & 1.51 & 1.27 & 1.08 & 1.46 & 1.60 & 1.92 & 1.63 & 1.46 & 1.71 & 1.29 & 1.57 \\
\hline & badhealth & Bad or very bad self-reported health & $22 \%$ & $20 \%$ & $10 \%$ & $27 \%$ & $19 \%$ & $34 \%$ & $24 \%$ & $21 \%$ & $29 \%$ & $17 \%$ & $13 \%$ \\
\hline & mobility & Number of activity limitations out of 10 listed & 1.48 & 1.55 & 0.88 & 1.41 & 1.22 & 2.23 & 1.49 & 1.72 & 1.62 & 1.18 & 1.30 \\
\hline & symptoms & Number of symptoms out of 11 listed & 1.48 & 1.34 & 1.01 & 1.50 & 1.49 & 2.02 & 1.61 & 1.36 & 1.60 & 1.18 & 1.61 \\
\hline \multirow{4}{*}{ Marital status } & marriedsep & Married but living separately & $1.2 \%$ & $2.1 \%$ & $2.2 \%$ & $1.0 \%$ & $1.6 \%$ & $1.7 \%$ & $1.3 \%$ & $1.1 \%$ & $0.6 \%$ & $0.8 \%$ & $0.6 \%$ \\
\hline & nevermarried & Never married & $5.9 \%$ & $8.8 \%$ & $5.5 \%$ & $5.2 \%$ & $6.6 \%$ & $7.1 \%$ & $7.0 \%$ & $4.6 \%$ & $6.4 \%$ & $4.1 \%$ & $4.3 \%$ \\
\hline & widow & Widow & $15.4 \%$ & $22.1 \%$ & $15.2 \%$ & $12.4 \%$ & $17.5 \%$ & $17.1 \%$ & $16.8 \%$ & $23.6 \%$ & $13.8 \%$ & $10.6 \%$ & $9.8 \%$ \\
\hline & divorced & Divorced & $6.0 \%$ & $8.7 \%$ & $8.9 \%$ & $6.1 \%$ & $13.1 \%$ & $1.6 \%$ & $8.7 \%$ & $3.8 \%$ & $1.6 \%$ & $4.3 \%$ & $7.7 \%$ \\
\hline \multirow{5}{*}{$\begin{array}{l}\text { Other socio-economic } \\
\text { characteristics }\end{array}$} & age & Age in years & 64.6 & 64.9 & 65.0 & 64.0 & 64.4 & 66.5 & 65.0 & 64.6 & 64.4 & 63.4 & 65.2 \\
\hline & female & Female & $54.6 \%$ & $57.5 \%$ & $53.4 \%$ & $53.2 \%$ & $53.8 \%$ & $58.3 \%$ & $55.1 \%$ & $54.4 \%$ & $54.9 \%$ & $52.8 \%$ & $53.1 \%$ \\
\hline & countrybirthyes & Born in interview country & $92.2 \%$ & $91.0 \%$ & $84.2 \%$ & $81.6 \%$ & $96.5 \%$ & $97.9 \%$ & $86.8 \%$ & $97.7 \%$ & $98.6 \%$ & $94.1 \%$ & $93.0 \%$ \\
\hline & yedu & Total years of education & 10.0 & 11.3 & 11.6 & 13.5 & 12.6 & 5.3 & 7.9 & 8.5 & 7.0 & 11.1 & 10.3 \\
\hline & employed & Employed & $26.7 \%$ & $16.8 \%$ & $37.0 \%$ & $28.9 \%$ & $35.9 \%$ & $18.2 \%$ & $25.3 \%$ & $25.6 \%$ & $17.3 \%$ & $29.0 \%$ & $38.9 \%$ \\
\hline \multirow[t]{5}{*}{ Life style } & weeksports & Participating in weekly sports activities & $50.2 \%$ & $42.5 \%$ & $59.8 \%$ & $56.9 \%$ & $60.1 \%$ & $35.6 \%$ & $42.1 \%$ & $52.8 \%$ & $40.6 \%$ & $57.6 \%$ & $54.3 \%$ \\
\hline & weekactivity & $\begin{array}{l}\text { Engaged in weekly activities that require a low or moderate level of } \\
\text { energy, such as gardening, cleaning the car, or doing a walk }\end{array}$ & $83.2 \%$ & $79.1 \%$ & $86.9 \%$ & $87.3 \%$ & $88.4 \%$ & $79.6 \%$ & $79.0 \%$ & $83.1 \%$ & $71.6 \%$ & $87.1 \%$ & $90.4 \%$ \\
\hline & smokestill & A smoker & $19.9 \%$ & $18.3 \%$ & $18.8 \%$ & $17.4 \%$ & $31.9 \%$ & $15.7 \%$ & $13.1 \%$ & $24.5 \%$ & $18.0 \%$ & $23.6 \%$ & $17.8 \%$ \\
\hline & formersmoker & A former smoker & $27.6 \%$ & $18.0 \%$ & $25.0 \%$ & $26.7 \%$ & $33.0 \%$ & $21.1 \%$ & $26.1 \%$ & $18.9 \%$ & $25.4 \%$ & $38.8 \%$ & $38.6 \%$ \\
\hline & alcodaily & Daily or almost daily alcohol consumption & $26.0 \%$ & $17.3 \%$ & $27.4 \%$ & $19.2 \%$ & $31.4 \%$ & $27.0 \%$ & $37.4 \%$ & $13.8 \%$ & $44.7 \%$ & $35.2 \%$ & $7.4 \%$ \\
\hline \multirow[t]{4}{*}{ Organisational features } & physsup & Physician supply/1000 & & 3.4 & 3.6 & 3.4 & 2.8 & 3.2 & 3.4 & 4.4 & 4.1 & 3.1 & 3.3 \\
\hline & accspec & Access restriction to specialists & & Yes & No & No & Yes & Yes & Yes & No & Yes & No & No \\
\hline & outofpocket & Out-of-pocket payment & & No & Yes & No & No & No & Yes & Yes & Yes & No & Yes \\
\hline & salary & Salary based provider payment & & No & No & No & No & Yes & No & No & No & No & Yes \\
\hline \multirow[t]{3}{*}{ Region } & North & Denmark, Sweden & & 0 & 0 & 0 & 1 & 0 & 0 & 0 & 0 & 0 & 1 \\
\hline & South & Greece, Italy, Spain & & 0 & 0 & 0 & 0 & 1 & 0 & 1 & 1 & 0 & 0 \\
\hline & Central & Austria, France, Germany, the Netherlands, Switzerland & & 1 & 1 & 1 & 0 & 0 & 1 & 0 & 0 & 1 & 0 \\
\hline
\end{tabular}


Table 3: Country mean residuals after regression on the total number of physicians visits

\begin{tabular}{|c|c|c|c|c|c|c|c|c|c|c|c|c|c|c|c|c|c|}
\hline \multirow[b]{3}{*}{ Austria (AT) } & \multicolumn{3}{|c|}{ Model 0: no covars } & \multicolumn{3}{|c|}{ Model 1: health } & \multicolumn{3}{|c|}{ Model 2: health+social } & \multicolumn{2}{|c|}{ Model 3: individual } & \multicolumn{3}{|c|}{ Model 4: ind+institutional } & \multicolumn{3}{|c|}{ Model 5: all } \\
\hline & \multirow{2}{*}{$\frac{\text { Mean }}{0.15}$} & \multicolumn{2}{|c|}{$95 \% \mathrm{CI}$} & \multirow{2}{*}{$\frac{\text { Mean }}{0.52}$} & \multicolumn{2}{|c|}{$95 \% \mathrm{CI}$} & \multirow{2}{*}{$\frac{\text { Mean }}{0.42}$} & \multicolumn{2}{|c|}{$95 \% \mathrm{CI}$} & \multirow{2}{*}{$\frac{\text { Mean }}{0.26}$} & $95 \% \mathrm{CI}$ & \multirow{2}{*}{$\begin{array}{r}\text { Mean } \\
-1.31\end{array}$} & \multicolumn{2}{|c|}{$95 \% \mathrm{CI}$} & \multirow{2}{*}{$\frac{\text { Mean }}{-1.23}$} & \multicolumn{2}{|c|}{$95 \% \mathrm{CI}$} \\
\hline & & $(-0.26$ & $0.64)$ & & $(0.14$ & $0.94)^{*}$ & & $(0.02$ & $0.86)^{*}$ & & $\left(\begin{array}{ll}-0.15 & 0.69\end{array}\right)$ & & $(-1.72$ & $-0.88)^{*}$ & & $(-1.65$ & $-0.79)^{*}$ \\
\hline Switzerland $(\mathrm{CH})$ & -1.67 & $(-2.13$ & $-1.17)^{*}$ & -0.30 & $(-0.74$ & $0.19)$ & -0.20 & $(-0.65$ & $0.28)$ & -0.17 & $\left(\begin{array}{ll}-0.62 & 0.32\end{array}\right)$ & 0.85 & $(0.39$ & $1.33)^{*}$ & 0.06 & $(-0.40$ & $0.54)$ \\
\hline Germany (DE) & 1.36 & $(0.98$ & $1.78)^{*}$ & 1.12 & $(0.75$ & $1.50)^{*}$ & 1.23 & $(0.87$ & $1.57)^{*}$ & 1.18 & $(0.81 \quad 1.53)^{*}$ & 1.14 & (0.81 & $1.50)^{*}$ & 1.04 & $(0.71$ & $1.41)^{*}$ \\
\hline Denmark (DK) & -2.01 & $(-2.40$ & $-1.62) *$ & -2.06 & $(-2.45$ & $-1.62)^{*}$ & -1.79 & $(-2.17$ & $-1.41)^{*}$ & -1.63 & $(-2.00-1.21)^{*}$ & -1.72 & $(-2.11$ & $-1.33)^{*}$ & 0.15 & $(-0.22$ & $0.53)$ \\
\hline Spain (ES) & 3.26 & $(2.62$ & $3.86)^{*}$ & 0.85 & $(0.23$ & $1.47)^{*}$ & 0.84 & $(0.22$ & $1.50)^{*}$ & 0.91 & $(0.331 .57)^{*}$ & 0.49 & $(-0.09$ & 1.14) & -0.79 & $(-1.43$ & $-0.16)^{*}$ \\
\hline France (FR) & 1.01 & $(0.62$ & $1.42)^{*}$ & 0.49 & (0.10 & $0.90)^{*}$ & 0.45 & $(0.04$ & $0.87)^{*}$ & 0.33 & $\left(\begin{array}{ll}-0.07 & 0.77\end{array}\right)$ & 1.01 & $(0.61$ & $1.39)^{*}$ & -0.42 & $(-0.82$ & $0.01)$ \\
\hline Greece (GR) & -0.80 & $(-1.15$ & $-0.45)^{*}$ & -1.03 & $(-1.34$ & $-0.69)^{*}$ & -1.07 & $(-1.38$ & $-0.75)$ & -1.00 & $\left(\begin{array}{ll}-1.33 & -0.69\end{array}\right) *$ & -1.33 & $(-1.65$ & $-0.99)^{*}$ & -0.64 & $(-0.96$ & $-0.34)^{*}$ \\
\hline $\begin{array}{l}\text { Italy (IT) } \\
\text { the Netherlands }\end{array}$ & 2.47 & $(1.96$ & $3.04)^{*}$ & 1.39 & $(0.89$ & $1.89)^{*}$ & 1.23 & $(0.73$ & $1.76)^{*}$ & 1.09 & $(0.61 \quad 1.59)^{*}$ & -0.15 & $(-0.61$ & $0.34)$ & 0.12 & $(-0.38$ & $0.58)$ \\
\hline$(\mathrm{NL})$ & -1.79 & $(-2.07$ & $-1.48)^{*}$ & -1.18 & $(-1.46$ & $-0.88)^{*}$ & -1.11 & $(-1.38$ & $-0.81)^{*}$ & -1.04 & $\left(\begin{array}{ll}-1.31 & -0.76\end{array}\right) *$ & -0.41 & $(-0.69$ & $-0.11)^{*}$ & -0.90 & $(-1.17$ & $-0.62)^{*}$ \\
\hline Sweden (SE) & -3.34 & $(-3.54$ & $-3.11)^{*}$ & -3.21 & $(-3.47$ & $-2.94)^{*}$ & -2.98 & $(-3.24$ & $-2.70)^{*}$ & -2.91 & $\left(\begin{array}{ll}-3.16 & -2.65\end{array}\right)^{*}$ & -0.82 & $(-1.04$ & $-0.59)^{*}$ & -0.26 & $(-0.47$ & $-(0.05)^{*}$ \\
\hline MSE & 4.13 & & & 2.03 & & & 1.77 & & & 1.59 & & 1.01 & & & 0.39 & & \\
\hline Explained MSE & $0 \%$ & & & $51 \%$ & & & $57 \%$ & & & $61 \%$ & & $76 \%$ & & & $91 \%$ & & \\
\hline
\end{tabular}

95\% Bootstrap confidence intervals; $*$ significant at $5 \%$; MSE $=$ Mean Squared Error between countries 
Table 4: Country mean residuals after regression on the number of GP visits

\begin{tabular}{|c|c|c|c|c|c|c|c|c|c|c|c|c|c|c|c|c|c|c|}
\hline \multirow[b]{2}{*}{ Austria (AT) } & \multicolumn{3}{|c|}{ Model 0 : no covars } & \multicolumn{3}{|c|}{ Model 1: health } & \multicolumn{3}{|c|}{ Model 2: health+social } & \multicolumn{3}{|c|}{ Model 3: individual } & \multicolumn{3}{|c|}{ Model 4: ind+institutional } & \multicolumn{3}{|c|}{ Model 5: all } \\
\hline & 0.31 & $(-0.02$ & $0.63)$ & 0.57 & $(0.27$ & $0.87)^{*}$ & 0.63 & $(0.34$ & $0.94)^{*}$ & 0.50 & $(0.19$ & $0.82)^{*}$ & -1.02 & $(-1.32$ & $-0.69)^{*}$ & -0.97 & $(-1.28$ & $-0.64)^{*}$ \\
\hline Switzerland $(\mathrm{CH})$ & -1.34 & $(-1.68$ & $-1.00)^{*}$ & -0.36 & $(-0.68$ & $-0.02)^{*}$ & -0.20 & $(-0.52$ & $0.15)$ & -0.17 & $(-0.49$ & $0.18)$ & 0.71 & $(0.39$ & $1.02)^{*}$ & 0.29 & $(-0.03$ & $0.61)$ \\
\hline Germany (DE) & 0.49 & $(0.22$ & $0.78)^{*}$ & 0.33 & $(0.08$ & $0.61)^{*}$ & 0.80 & $(0.56$ & $1.07)^{*}$ & 0.78 & $(0.53$ & $1.06)^{*}$ & 0.91 & $(0.65$ & $1.17)^{*}$ & 0.86 & $(0.59$ & $1.13)^{*}$ \\
\hline Denmark (DK) & -1.21 & $(-1.48$ & $-0.94)^{*}$ & -1.23 & $(-1.50$ & $-0.96)^{*}$ & -0.84 & $(-1.09$ & $-0.55)^{*}$ & -0.69 & $(-0.94$ & $-0.43)^{*}$ & -1.05 & $(-1.32$ & $-0.81)^{*}$ & 0.17 & $(-0.08$ & $0.44)$ \\
\hline Spain (ES) & 2.98 & $(2.48$ & $3.52)^{*}$ & 1.24 & $(0.73$ & $1.81)^{*}$ & 0.73 & $(0.22$ & $1.31)^{*}$ & 0.74 & $(0.21$ & $1.27)^{*}$ & 0.39 & $(-0.13$ & $0.93)$ & -0.54 & $(-1.10$ & $0.02)$ \\
\hline France (FR) & 1.01 & $(0.74$ & $1.34)^{*}$ & 0.64 & $(0.35$ & $0.94)^{*}$ & 0.39 & $(0.11$ & $0.69)^{*}$ & 0.28 & $(-0.02$ & $0.59)$ & 0.67 & $(0.39$ & $0.98)^{*}$ & -0.26 & $(-0.55$ & $0.02)$ \\
\hline Greece (GR) & -0.78 & $(-1.05$ & $-0.49)^{*}$ & -0.95 & $(-1.23$ & $-0.66)^{*}$ & -1.20 & $(-1.49$ & $-0.89)^{*}$ & -1.16 & $(-1.45$ & $-0.88)^{*}$ & -1.00 & $(-1.27$ & $-0.71)^{*}$ & -0.56 & $(-0.85$ & $-0.27)^{*}$ \\
\hline $\begin{array}{l}\text { Italy (IT) } \\
\text { the Netherlands }\end{array}$ & 2.39 & $(1.94$ & $2.86)^{*}$ & 1.61 & $(1.20$ & $2.07)^{*}$ & 1.25 & $(0.85$ & $1.68)^{*}$ & 1.11 & $(0.68$ & $1.59)^{*}$ & -0.12 & $(-0.55$ & $0.29)$ & 0.10 & $(-0.34$ & $0.52)$ \\
\hline$(\mathrm{NL})$ & -1.75 & $(-1.92$ & $-1.57)^{*}$ & -1.32 & $(-1.49$ & $-1.15)^{*}$ & -1.13 & $(-1.29$ & $-0.97)^{*}$ & -1.06 & $(-1.21$ & $-0.88)^{*}$ & -0.43 & $(-0.58$ & $-0.26)^{*}$ & -0.69 & $(-0.85$ & $-0.53)^{*}$ \\
\hline Sweden (SE) & -2.68 & $(-2.82$ & $-2.55)^{*}$ & -2.58 & $(-2.76$ & $-2.41)^{*}$ & -2.34 & $(-2.51$ & $-2.15)^{*}$ & -2.26 & $(-2.42$ & $-2.08) *$ & -0.54 & $(-0.66$ & $-0.40)^{*}$ & -0.23 & $(-0.35$ & $-0.09)^{*}$ \\
\hline MSE & 3.01 & & & 1.55 & & & 1.19 & & & 1.04 & & & 0.53 & & & 0.27 & & \\
\hline Explained MSE & $0 \%$ & & & $48 \%$ & & & $61 \%$ & & & $65 \%$ & & & $82 \%$ & & & $91 \%$ & & \\
\hline
\end{tabular}

95\% Bootstrap confidence intervals; * significant at 5\%; MSE = Mean Squared Error between countries 
Table 5: Country mean residuals after regression on the number of specialist visits

\begin{tabular}{|c|c|c|c|c|c|c|c|c|c|c|c|c|c|c|c|c|c|c|}
\hline \multirow[b]{2}{*}{ Austria (AT) } & \multicolumn{3}{|c|}{ Model 0: no covars } & \multicolumn{3}{|c|}{ Model 1: health } & \multicolumn{3}{|c|}{ Model 2: health+social } & \multicolumn{3}{|c|}{ Model 3: individual } & \multicolumn{3}{|c|}{ Model 4: ind+institutional } & \multicolumn{3}{|c|}{ Model 5: all } \\
\hline & -0.17 & $(-0.40$ & $0.10)$ & -0.05 & $(-0.28$ & $0.20)$ & -0.18 & $(-0.42$ & $0.08)$ & -0.21 & $(-0.44$ & $0.07)$ & -0.26 & $(-0.49$ & $-0.01)^{*}$ & -0.33 & $(-0.56$ & $-0.06)^{*}$ \\
\hline Switzerland $(\mathrm{CH})$ & -0.33 & $(-0.65$ & $0.01)$ & 0.06 & $(-0.23$ & $0.43)$ & 0.03 & $(-0.27$ & $0.37)$ & 0.04 & $(-0.25$ & $0.38)$ & 0.17 & $(-0.11$ & $0.53)$ & -0.23 & $(-0.52$ & $0.12)$ \\
\hline Germany (DE) & 0.87 & $(0.65$ & $1.09)^{*}$ & 0.80 & $(0.59$ & $1.02)^{*}$ & 0.40 & $(0.20$ & $0.64)^{*}$ & 0.39 & $(0.17$ & $0.61)^{*}$ & 0.11 & $(-0.11$ & $0.34)$ & 0.03 & $(-0.17$ & $0.26)$ \\
\hline Denmark (DK) & -0.80 & $(-1.07$ & $-0.49)^{*}$ & -0.83 & $(-1.09$ & $-0.55)^{*}$ & -0.99 & $(-1.24$ & $-0.70)^{*}$ & -0.94 & $(-1.20$ & $-0.65)^{*}$ & -0.61 & $(-0.87$ & $-0.32)^{*}$ & 0.10 & $(-0.15$ & $0.39)$ \\
\hline Spain (ES) & 0.28 & $(0.04$ & $0.53)^{*}$ & -0.38 & $(-0.64$ & $-0.11)^{*}$ & 0.05 & $(-0.18$ & $0.32)$ & 0.07 & $(-0.16$ & $0.32)$ & 0.10 & $(-0.13$ & $0.35)$ & -0.27 & $(-0.50$ & $0.01)$ \\
\hline France (FR) & 0.01 & $(-0.23$ & $0.25)$ & -0.14 & $(-0.37$ & $0.16)$ & 0.02 & $(-0.22$ & $0.27)$ & 0.03 & $(-0.20$ & $0.30)$ & 0.42 & $(0.19$ & $0.68)^{*}$ & -0.08 & $(-0.32$ & $0.16)$ \\
\hline Greece (GR) & -0.03 & $(-0.21$ & $0.17)$ & -0.07 & $(-0.27$ & $0.14)$ & 0.10 & $(-0.08$ & $0.29)$ & 0.09 & $(-0.08$ & $0.28)$ & -0.28 & $(-0.46$ & $-0.09)^{*}$ & -0.03 & $(-0.21$ & $0.16)$ \\
\hline $\begin{array}{l}\text { Italy (IT) } \\
\text { the Netherlands }\end{array}$ & 0.08 & $(-0.14$ & $0.30)$ & -0.22 & $(-0.42$ & $0.00)$ & -0.04 & $(-0.27$ & $0.17)$ & -0.02 & $(-0.23$ & $0.20)$ & -0.05 & $(-0.26$ & $0.18)$ & 0.04 & $(-0.15$ & $0.24)$ \\
\hline (NL) & -0.03 & $(-0.24$ & $0.20)$ & 0.15 & $(-0.07$ & $0.38)$ & 0.03 & $(-0.19$ & $0.26)$ & 0.03 & $(-0.18$ & $0.27)$ & 0.00 & $(-0.20$ & $0.23)$ & -0.20 & $(-0.42$ & $0.06)$ \\
\hline Sweden (SE) & -0.66 & $(-0.81$ & $-0.50)^{*}$ & -0.62 & $(-0.78$ & $-0.44)^{*}$ & -0.61 & $(-0.78$ & $-0.44)^{*}$ & -0.66 & $(-0.83$ & $-0.50)^{*}$ & -0.34 & $(-0.50$ & $-0.16)^{*}$ & -0.11 & $(-0.27$ & $0.05)$ \\
\hline MSE & 0.20 & & & 0.18 & & & 0.14 & & & 0.14 & & & 0.08 & & & 0.02 & & \\
\hline Explained MSE & $0 \%$ & & & $11 \%$ & & & $29 \%$ & & & $30 \%$ & & & $60 \%$ & & & $91 \%$ & & \\
\hline
\end{tabular}

95\% Bootstrap confidence intervals; * significant at 5\%; MSE = Mean Squared Error between countries 
Table 6: Regressions on the total number of physician visits

\begin{tabular}{|c|c|c|c|c|c|c|c|c|c|c|c|c|c|c|c|c|c|c|c|}
\hline \multirow[b]{2}{*}{ Health } & \multirow[b]{2}{*}{ chronic } & \multicolumn{3}{|c|}{ Model 0: no covars } & \multicolumn{3}{|c|}{ Model 1: health } & \multicolumn{3}{|c|}{ Model 2: health+social } & \multicolumn{3}{|c|}{ Model 3: individual } & \multicolumn{3}{|c|}{ Model 4: ind+institutional } & \multicolumn{3}{|c|}{ Model 5: all } \\
\hline & & & & & 0.19 & $(0.18$ & $0.20) * *$ & 0.18 & $(0.16$ & $0.19)^{* *}$ & 0.18 & $(0.16$ & $0.19)^{* *}$ & 0.18 & $(0.17$ & $0.19)^{* *}$ & 0.19 & $(0.17$ & $0.20) * *$ \\
\hline & badhealth & & & & 0.47 & $(0.43$ & $0.51)^{* *}$ & 0.45 & $(0.41$ & $0.49)^{* *}$ & 0.43 & $(0.39$ & $0.47)^{* *}$ & 0.40 & $(0.36$ & $0.44)^{* *}$ & 0.40 & $(0.36$ & $0.44)^{* *}$ \\
\hline & mobility & & & & 0.07 & $(0.06$ & $0.08)^{* *}$ & 0.07 & $(0.06$ & $0.08)^{* *}$ & 0.06 & $(0.05$ & $0.07)^{* *}$ & 0.05 & $(0.04$ & $0.06)^{* *}$ & 0.05 & $(0.04$ & $0.06)^{* *}$ \\
\hline & symptoms & & & & 0.06 & $(0.05$ & $0.07)^{* *}$ & 0.06 & $(0.05$ & $0.07)^{* *}$ & 0.06 & $(0.05$ & $0.07)^{* *}$ & 0.07 & $(0.05$ & $0.08)^{* *}$ & 0.07 & $(0.06$ & $0.08)^{* *}$ \\
\hline \multirow[t]{11}{*}{ Social } & age & & & & & & & 0.03 & $(0.01$ & $0.05)^{* *}$ & 0.03 & $(0.01$ & $0.05)^{* *}$ & 0.03 & $(0.01$ & $0.05)^{* *}$ & 0.04 & $(0.02$ & $0.06)^{* *}$ \\
\hline & agesquare & & & & & & & 0.00 & $(-0.00$ & $-0.00) * *$ & 0.00 & $(-0.00$ & $-0.00) * *$ & 0.00 & $(-0.00$ & $-0.00)^{*}$ & 0.00 & $(-0.00$ & $-0.00) * *$ \\
\hline & female & & & & & & & 1.04 & $(0.83$ & $1.26)^{* *}$ & 1.05 & $(0.84$ & $1.27)^{* *}$ & 1.02 & $(0.80$ & $1.23)^{* *}$ & 1.00 & $(0.79$ & $1.21)^{* *}$ \\
\hline & female*age & & & & & & & -0.02 & $(-0.02$ & $-0.01)^{* *}$ & -0.02 & $(-0.02$ & $-0.01)^{* *}$ & -0.02 & $(-0.02$ & $-0.01)^{* *}$ & -0.02 & $(-0.02$ & $-0.01)^{* *}$ \\
\hline & nevermarried & & & & & & & 0.20 & $(0.13$ & $0.27)^{* *}$ & 0.18 & $(0.11$ & $0.25)^{* *}$ & 0.16 & $(0.09$ & $0.24)^{* *}$ & 0.17 & $(0.09$ & $0.24)^{* *}$ \\
\hline & divorced & & & & & & & ns & & & ns & & & 0.07 & $(-0.01$ & $0.15)$ & 0.08 & $(0.01$ & $0.16)^{*}$ \\
\hline & female*married & & & & & & & 0.08 & $(0.02$ & $0.15)^{*}$ & 0.06 & $(-0.00$ & $0.13)$ & 0.08 & $(0.00$ & $0.16)^{*}$ & 0.08 & $(0.00$ & $0.16)^{*}$ \\
\hline & female*widow & & & & & & & 0.21 & $(0.14$ & $0.29)^{* *}$ & 0.20 & $(0.13$ & $0.28)^{* *}$ & 0.17 & $(0.08$ & $0.26)^{* *}$ & 0.18 & $(0.09$ & $0.27)^{* *}$ \\
\hline & employed & & & & & & & -0.27 & $(-0.31$ & $-0.22)^{* *}$ & -0.27 & $(-0.31$ & $-0.22)^{* *}$ & -0.19 & $(-0.24$ & $-0.15)^{* *}$ & -0.18 & $(-0.23$ & $-0.14)^{* *}$ \\
\hline & countrybirthyes & & & & & & & -0.06 & $(-0.11$ & $-0.00)^{*}$ & -0.05 & $(-0.11$ & $0.00)$ & -0.10 & $(-0.16$ & $-0.05)^{* *}$ & -0.06 & $(-0.12$ & $-0.01)^{*}$ \\
\hline & yedu & & & & & & & 0.00 & $(-0.01$ & $0.00)$ & $\mathrm{ns}$ & & & ns & & & 0.01 & $(0.01$ & $0.01)^{* *}$ \\
\hline \multirow[t]{5}{*}{ Lifestyle } & formersmoker & & & & & & & & & & -0.04 & $(-0.07$ & $0.00)$ & ns & & & 0.05 & $(0.01$ & $0.09)^{*}$ \\
\hline & smokestill & & & & & & & & & & -0.18 & $(-0.22$ & $-0.14)^{* *}$ & -0.16 & $(-0.20$ & $-0.12)^{* *}$ & -0.10 & $(-0.15$ & $-0.06)^{* *}$ \\
\hline & weekactivity & & & & & & & & & & -0.14 & $(-0.19$ & $-0.10)^{* *}$ & -0.10 & $(-0.15$ & $-0.06)^{* *}$ & -0.09 & $(-0.14$ & $-0.05)^{* *}$ \\
\hline & weeksports & & & & & & & & & & -0.09 & $(-0.12$ & $-0.05) * *$ & -0.07 & $(-0.11$ & $-0.04)^{* *}$ & -0.05 & $(-0.09$ & $-0.02)^{* *}$ \\
\hline & alcodaily & & & & & & & & & & ns & & & -0.06 & $(-0.09$ & $-0.02)^{* *}$ & -0.10 & $(-0.13$ & $-0.06)^{* *}$ \\
\hline \multirow[t]{4}{*}{ Institution } & physician supply & & & & & & & & & & & & & 0.39 & $(0.34$ & $0.44)^{* *}$ & 0.06 & $(-0.00$ & $0.12)$ \\
\hline & access restriction & ecialists & & & & & & & & & & & & 0.24 & $(0.21$ & $0.27)^{* *}$ & 0.24 & $(0.21$ & $0.27)^{* *}$ \\
\hline & outofpocket & & & & & & & & & & & & & -0.33 & $(-0.37$ & $-0.29)^{* *}$ & -0.07 & $(-0.12$ & $-0.02)^{* *}$ \\
\hline & salary based & & & & & & & & & & & & & -0.09 & $(-0.14$ & $-0.05) * *$ & 0.04 & $(-0.01$ & $0.08)$ \\
\hline \multirow[t]{5}{*}{ Region } & North $=$ Denmar & & & & & & & & & & & & & & & & -0.59 & $(-0.65$ & $-0.53)^{* *}$ \\
\hline & Constant & 1.85 & $(1.83$ & $1.86)^{* *}$ & 1.10 & $(1.08$ & $1.13)^{* *}$ & 0.03 & $(-0.64$ & $0.71)$ & 0.36 & $(-0.31$ & 1.04) & -1.10 & $(-1.79$ & $-0.42)^{* *}$ & -0.49 & $(-1.18$ & $0.20)$ \\
\hline & Inalpha & 0.23 & $(0.21$ & $0.26)$ & -0.08 & $(-0.10$ & $-0.05)$ & -0.10 & $(-0.12$ & $-0.08)$ & -0.11 & $(-0.14$ & $-0.09)$ & -0.14 & $(-0.17$ & $-0.12)$ & -0.17 & $(-0.20$ & $-0.14)$ \\
\hline & alpha & 1.26 & $(1.24$ & 1.29) & 0.93 & $(0.90$ & $0.95)$ & 0.90 & $(0.88$ & $0.93)$ & 0.90 & $(0.87$ & $0.92)$ & 0.87 & $(0.84$ & 0.89) & 0.84 & $(0.82$ & $0.87)$ \\
\hline & Pseudo R2 & $0 \%$ & & & $4.43 \%$ & & & $4.78 \%$ & & & $4.92 \%$ & & & $5.38 \%$ & & & $5.76 \%$ & & \\
\hline
\end{tabular}

95\% Confidence intervals; $*$ significant at 5\%; ** significant at 1\%; Variables not significant in any model: marriedsep, widow, female *agesquare, female*divorced, South=Spain, Italy, Greece 
Table 7: Regressions on the number of GP visits

\begin{tabular}{|c|c|c|c|c|c|c|c|c|c|c|c|c|c|c|c|c|c|c|c|}
\hline \multirow[b]{2}{*}{ Health } & \multirow[b]{2}{*}{ Chronic } & \multicolumn{3}{|c|}{ Model 0: no covars } & \multicolumn{3}{|c|}{ Model 1: health } & \multicolumn{3}{|c|}{ Model 2: health+social } & \multicolumn{3}{|c|}{ Model 3: individual } & \multicolumn{3}{|c|}{ Model 4: ind+institutional } & \multicolumn{3}{|c|}{ Model 5: all } \\
\hline & & & & & 0.19 & $(0.18$ & $0.21)^{* *}$ & 0.17 & $(0.16$ & $0.18)^{* *}$ & 0.17 & $(0.16$ & $0.19)^{* *}$ & 0.17 & $(0.16$ & $0.19)^{* *}$ & 0.18 & $(0.17$ & $0.19)^{* *}$ \\
\hline & Badhealth & & & & 0.45 & $(0.41$ & $0.50)^{* *}$ & 0.42 & $(0.38$ & $0.47)^{* *}$ & 0.40 & $(0.36$ & $0.44)^{* *}$ & 0.37 & $(0.33$ & $0.42)^{* *}$ & 0.38 & $(0.33$ & $0.42)^{* *}$ \\
\hline & Mobility & & & & 0.08 & $(0.07$ & $0.09)^{* *}$ & 0.06 & $(0.05$ & $0.07)^{* *}$ & 0.05 & $(0.04$ & $0.06)^{* *}$ & 0.05 & $(0.04$ & $0.06)^{* *}$ & 0.05 & $(0.04$ & $0.06) * *$ \\
\hline & Symptoms & & & & 0.05 & $(0.04$ & $0.07)^{* *}$ & 0.05 & $(0.04$ & $0.07)^{* *}$ & 0.05 & $(0.04$ & $0.07)^{* *}$ & 0.06 & $(0.05$ & $0.07)^{* *}$ & 0.06 & $(0.05$ & $0.08)^{* *}$ \\
\hline \multirow[t]{13}{*}{ Social } & Age & & & & & & & 0.04 & $(0.02$ & $0.06)^{* *}$ & 0.04 & $(0.02$ & $0.06)^{* *}$ & 0.04 & $(0.02$ & $0.06)^{* *}$ & 0.04 & $(0.02$ & $0.06)^{* *}$ \\
\hline & Agesquare & & & & & & & 0.00 & $(-0.00$ & $-0.00)^{* *}$ & 0.00 & $(-0.00$ & $-0.00)^{* *}$ & 0.00 & $(-0.00$ & $-0.00)^{* *}$ & 0.00 & $(-0.00$ & $-0.00)^{* *}$ \\
\hline & Female & & & & & & & 0.66 & $(0.41$ & $0.91)^{* *}$ & 0.67 & $(0.41$ & $0.92)^{* *}$ & 0.75 & $(0.52$ & $0.98)^{* *}$ & 0.77 & $(0.54$ & $0.99)^{* *}$ \\
\hline & female*age & & & & & & & -0.01 & $(-0.02$ & $-0.01)^{* *}$ & -0.01 & $(-0.02$ & $-0.01)^{* *}$ & -0.01 & $(-0.02$ & $-0.01)^{* *}$ & -0.01 & $(-0.02$ & $-0.01)^{* *}$ \\
\hline & Marriedsep & & & & & & & 0.16 & $(-0.01$ & $0.32)$ & 0.17 & $(0.01$ & $0.34)^{*}$ & ns & & & & & \\
\hline & Nevermarried & & & & & & & 0.26 & $(0.17$ & $0.35)^{* *}$ & 0.24 & $(0.14$ & $0.33)^{* *}$ & 0.13 & $(0.05$ & $0.20)^{* *}$ & 0.12 & $(0.05$ & $0.20)^{* *}$ \\
\hline & Widow & & & & & & & 0.19 & $(0.09$ & $0.29)^{* *}$ & 0.18 & $(0.08$ & $0.28)^{* *}$ & 0.17 & $(0.11$ & $0.23)^{* *}$ & 0.18 & $(0.11$ & $0.24)^{* *}$ \\
\hline & female*married & & & & & & & 0.20 & $(0.08$ & $0.31)^{* *}$ & 0.19 & $(0.07$ & $0.30)^{* *}$ & 0.06 & $(-0.00$ & $0.12)$ & 0.06 & $(-0.01$ & $0.12)$ \\
\hline & female*divorced & & & & & & & 0.12 & $(-0.02$ & $0.26)$ & 0.14 & $(0.00$ & $0.28)^{*}$ & $\mathrm{~ns}$ & & & ns & & \\
\hline & female*widow & & & & & & & 0.17 & $(0.02$ & $0.33)^{*}$ & 0.17 & $(0.02$ & $0.33)^{*}$ & $\mathrm{~ns}$ & & & $\mathrm{~ns}$ & & \\
\hline & Employed & & & & & & & -0.27 & $(-0.32$ & $-0.22)^{* *}$ & -0.26 & $(-0.31$ & $-0.21)^{* *}$ & -0.18 & $(-0.23$ & $-0.13)^{* *}$ & -0.17 & $(-0.22$ & $-0.12)^{* *}$ \\
\hline & Countrybirthyes & & & & & & & ns & & & ns & & & -0.11 & $(-0.17$ & $-0.05)^{* *}$ & -0.07 & $(-0.13$ & $-0.01)^{*}$ \\
\hline & Yedu & & & & & & & -0.02 & $(-0.03$ & $-0.02)^{* *}$ & -0.02 & $(-0.02$ & $-0.02)^{* *}$ & -0.01 & $(-0.02$ & $-0.01)^{* *}$ & 0.00 & $(-0.01$ & $-0.00)^{*}$ \\
\hline \multirow[t]{5}{*}{ Lifestyle } & Formersmoker & & & & & & & & & & -0.09 & $(-0.13$ & $-0.05)^{* *}$ & ns & & & ns & & \\
\hline & Smokestill & & & & & & & & & & -0.20 & $(-0.25$ & $-0.16)^{* *}$ & -0.16 & $(-0.20$ & $-0.11)^{* *}$ & -0.12 & $(-0.16$ & $-0.08)^{* *}$ \\
\hline & Weekactivity & & & & & & & & & & -0.16 & $(-0.21$ & $-0.11)^{* *}$ & -0.11 & $(-0.16$ & $-0.07)^{* *}$ & -0.10 & $(-0.15$ & $-0.06)^{* *}$ \\
\hline & Weeksports & & & & & & & & & & -0.11 & $(-0.14$ & $-0.07)^{* *}$ & -0.08 & $(-0.12$ & $-0.05)^{* *}$ & -0.06 & $(-0.10$ & $-0.03)^{* *}$ \\
\hline & Alcodaily & & & & & & & & & & ns & & & -0.04 & $(-0.08$ & $-0.01)^{*}$ & -0.08 & $(-0.11$ & $-0.04)^{* *}$ \\
\hline \multirow[t]{4}{*}{ Intitutional } & \multicolumn{4}{|c|}{ physician supply/1000 } & & & & & & & & & & 0.43 & $(0.37$ & $0.48)^{* *}$ & 0.13 & $(0.07$ & $0.20)^{* *}$ \\
\hline & \multicolumn{4}{|c|}{ access restriction to specialists } & & & & & & & & & & 0.39 & $(0.35$ & $0.42)^{* *}$ & 0.38 & $(0.35$ & $0.42)^{* *}$ \\
\hline & \multicolumn{4}{|c|}{ Outofpocket } & & & & & & & & & & -0.36 & $(-0.40$ & $-0.31)^{* *}$ & -0.13 & $(-0.18$ & $-0.08)^{* *}$ \\
\hline & \multicolumn{4}{|l|}{ salary based } & & & & & & & & & & -0.12 & $(-0.17$ & $-0.07)^{* *}$ & ns & & \\
\hline \multirow[t]{5}{*}{ Region } & \multicolumn{4}{|c|}{ North=Denmark, Sweden } & & & & & & & & & & & & & -0.52 & $(-0.58$ & $-0.46)^{* *}$ \\
\hline & Constant & 1.50 & $(1.48$ & $1.52)^{* *}$ & 0.74 & $(0.72$ & $0.77)^{* *}$ & -0.44 & $(-1.17$ & $0.29)$ & -0.07 & $(-0.80$ & $0.66)$ & -1.75 & $(-2.49$ & $-1.01)^{* *}$ & -1.15 & $(-1.89$ & $-0.40)^{* *}$ \\
\hline & Lnalpha & 0.36 & $(0.33$ & $0.38)$ & 0.05 & $(0.03$ & $0.08)$ & 0.01 & $(-0.02$ & $0.04)$ & 0.00 & $(-0.03$ & $0.02)$ & -0.06 & $(-0.08$ & $-0.03)$ & -0.08 & $(-0.10$ & $-0.05)$ \\
\hline & Alpha & 1.43 & (1.39) & 1.46) & 1.05 & (1.03 & $1.08)$ & 1.01 & $(0.98$ & $1.04)$ & 1.00 & $(0.97$ & $1.02)$ & 0.94 & $(0.92$ & $0.97)$ & 0.93 & $(0.90$ & $0.95)$ \\
\hline & Pseudo R2 & $0 \%$ & & & $4.43 \%$ & & & $5.06 \%$ & & & $5.24 \%$ & & & $5.98 \%$ & & & $6.25 \%$ & & \\
\hline
\end{tabular}

95\% Confidence intervals; * significant at 5\%; ** significant at 1\%; Variables not significant in any model: divorced, female*agesquare, South=Spain, Italy, Greece 
Table 8: Regressions on the number of specialist visits

\begin{tabular}{|c|c|c|c|c|c|c|c|c|c|c|c|c|c|c|c|c|c|c|}
\hline \multirow[b]{2}{*}{ Health } & \multirow[b]{2}{*}{ Chronic } & \multicolumn{2}{|c|}{ Model 0: no covars } & \multicolumn{3}{|c|}{ Model 1: health } & \multicolumn{3}{|c|}{ Model 2: health+social } & \multicolumn{3}{|c|}{ Model 3: individual } & \multicolumn{3}{|c|}{$\begin{array}{c}\text { Model 4: } \\
\text { ind+institutional }\end{array}$} & \multicolumn{3}{|c|}{ Model 5: all } \\
\hline & & & & 0.17 & $(0.15$ & $0.20)^{* *}$ & 0.20 & $(0.17$ & $0.22)^{* *}$ & 0.20 & $(0.17$ & $0.22)^{* *}$ & 0.20 & $(0.17$ & $0.23)^{* *}$ & 0.21 & $(0.19$ & $0.24)^{* *}$ \\
\hline & Badhealth & & & 0.49 & $(0.42$ & $0.57)^{* *}$ & 0.52 & $(0.45$ & $0.60)^{* *}$ & 0.51 & $(0.43$ & $0.59)^{* *}$ & 0.48 & $(0.41$ & $0.56)^{* *}$ & 0.50 & $(0.42$ & $0.57)^{* *}$ \\
\hline & Mobility & & & 0.05 & $(0.03$ & $0.06)^{* *}$ & 0.07 & $(0.06$ & $0.09)^{* *}$ & 0.07 & $(0.05$ & $0.09)^{* *}$ & 0.06 & $(0.04$ & $0.08)^{* *}$ & 0.06 & $(0.04$ & $0.08)^{* *}$ \\
\hline & Symptoms & & & 0.08 & $(0.06$ & $0.11)^{* *}$ & 0.08 & $(0.05$ & $0.10)^{* *}$ & 0.08 & $(0.05$ & $0.10)^{* *}$ & 0.08 & $(0.06$ & $0.11)^{* *}$ & 0.08 & $(0.06$ & $0.11)^{* *}$ \\
\hline \multirow[t]{12}{*}{ Social } & Age & & & & & & 0.08 & $(0.02$ & $0.13)^{* *}$ & 0.07 & $(0.02$ & $0.13)^{* *}$ & 0.07 & $(0.02$ & $0.13)^{* *}$ & 0.09 & $(0.04$ & $0.15)^{* *}$ \\
\hline & Agesquare & & & & & & 0.00 & $(-0.00$ & $-0.00)^{* *}$ & 0.00 & $(-0.00$ & $-0.00)^{* *}$ & 0.00 & $(-0.00$ & $-0.00)^{* *}$ & 0.00 & $(-0.00$ & $-0.00)^{* *}$ \\
\hline & Female & & & & & & 4.03 & $(1.74$ & $6.32)^{* *}$ & 4.04 & $(1.75$ & $6.32)^{* *}$ & 4.05 & $(1.77$ & $6.33)^{* *}$ & 4.53 & $(2.26$ & $6.80)^{* *}$ \\
\hline & female*age & & & & & & -0.10 & $(-0.17$ & $-0.03)^{* *}$ & -0.10 & $(-0.17$ & $-0.03)^{* *}$ & -0.10 & $(-0.17$ & $-0.03)^{* *}$ & -0.12 & $(-0.18$ & $-0.05)^{* *}$ \\
\hline & female*agesquare & & & & & & 0.00 & $(0.00$ & $0.00)^{*}$ & 0.00 & $(0.00$ & $0.00)^{*}$ & 0.00 & $(0.00$ & $0.00)^{*}$ & 0.00 & $(0.00$ & $0.00)^{* *}$ \\
\hline & Marriedsep & & & & & & -0.45 & $(-0.72$ & $-0.18)^{* *}$ & -0.43 & $(-0.70$ & $-0.16)^{* *}$ & -0.44 & $(-0.71$ & $-0.17)^{* *}$ & -0.48 & $(-0.75$ & $-0.21)^{* *}$ \\
\hline & Nevermarried & & & & & & 0.13 & $(0.01$ & $0.25)^{*}$ & 0.13 & $(0.01$ & $0.26)^{*}$ & 0.16 & $(0.03$ & $0.28)^{*}$ & 0.16 & $(0.04$ & $(0.28)^{* *}$ \\
\hline & Widow & & & & & & -0.48 & $(-0.67$ & $-0.29)^{* *}$ & -0.47 & $(-0.66$ & $-0.28)^{* *}$ & -0.48 & $(-0.66$ & $-0.29)^{* *}$ & -0.44 & $(-0.63$ & $-0.25)^{* *}$ \\
\hline & female*widow & & & & & & 0.54 & $(0.32$ & $0.75)^{* *}$ & 0.52 & $(0.31$ & $0.74)^{* *}$ & 0.50 & $(0.28$ & $0.72)^{* *}$ & 0.45 & $(0.24$ & $0.67)^{* *}$ \\
\hline & Employed & & & & & & -0.28 & $(-0.37$ & $-0.20)^{* *}$ & -0.30 & $(-0.38$ & $-0.22)^{* *}$ & -0.26 & $(-0.34$ & $-0.17)^{* *}$ & -0.24 & $(-0.33$ & $-0.16)^{* *}$ \\
\hline & Countrybirthyes & & & & & & -0.09 & $(-0.20$ & $0.01)$ & -0.09 & $(-0.19$ & $0.02)$ & -0.10 & $(-0.20$ & $0.01)$ & ns & & \\
\hline & Yedu & & & & & & 0.05 & $(0.04$ & $0.05)^{* *}$ & 0.05 & $(0.04$ & $0.05)^{* *}$ & 0.04 & $(0.03$ & $0.05)^{* *}$ & 0.05 & $(0.04$ & $0.06)^{* *}$ \\
\hline \multirow[t]{5}{*}{ Lifestyle } & Formersmoker & & & & & & & & & 0.10 & $(0.03$ & $0.17)^{* *}$ & 0.12 & $(0.04$ & $0.19)^{* *}$ & 0.18 & $(0.11$ & $0.24)^{* *}$ \\
\hline & Smokestill & & & & & & & & & -0.11 & $(-0.19$ & $-0.03)^{* *}$ & -0.11 & $(-0.19$ & $-0.03)^{* *}$ & ns & & \\
\hline & Weekactivity & & & & & & & & & -0.09 & $(-0.17$ & $-0.01)^{*}$ & -0.08 & $(-0.16$ & $0.01)$ & -0.08 & $(-0.17$ & $-0.00)^{*}$ \\
\hline & Weeksports & & & & & & & & & ns & & & -0.06 & $(-0.13$ & $0.00)$ & ns & & \\
\hline & Alcodaily & & & & & & & & & -0.14 & $(-0.20$ & $-0.07)^{* *}$ & -0.11 & $(-0.18$ & $-0.04)^{* *}$ & -0.15 & $(-0.22$ & $-0.08)^{* *}$ \\
\hline \multirow[t]{4}{*}{ Institutional } & physician supply/1 & & & & & & & & & & & & 0.36 & $(0.27$ & $0.45)^{* *}$ & 0.11 & $(-0.01$ & $0.23)$ \\
\hline & access restriction $\mathrm{t}$ & ecialist & & & & & & & & & & & -0.09 & $(-0.15$ & $-0.03)^{* *}$ & -0.07 & $(-0.14$ & $0.00)$ \\
\hline & Outofpocket & & & & & & & & & & & & -0.29 & $(-0.37$ & $-0.21)^{* *}$ & ns & & \\
\hline & salary based & & & & & & & & & & & & $\mathrm{ns}$ & & & 0.28 & $(0.18$ & $0.39)^{* *}$ \\
\hline \multirow[t]{6}{*}{ Region } & North=Denmark, & den & & & & & & & & & & & & & & -0.79 & $(-0.89$ & $-0.70)^{* *}$ \\
\hline & South $=$ Greece, $\mathrm{I}$ & Spain & & & & & & & & & & & & & & -0.18 & $(-0.30$ & $-0.05)^{* *}$ \\
\hline & Constant & 0.62 & $\left.\begin{array}{ll}0.59 & 0.65\end{array}\right)^{* *}$ & -0.09 & $(-0.13$ & $-0.04)^{* *}$ & -3.04 & $(-4.87$ & $-1.20)^{* *}$ & -2.80 & $(-4.64$ & $-0.97) * *$ & -3.76 & $(-5.62$ & $-1.90) * *$ & -3.81 & $(-5.67$ & $-1.96)^{* *}$ \\
\hline & Lnalpha & 1.38 & $\left(\begin{array}{ll}1.35 & 1.41\end{array}\right)$ & 1.24 & $(1.20$ & 1.27) & 1.19 & $(1.16$ & $1.22)$ & 1.19 & $(1.16$ & $1.22)$ & 1.18 & $(1.15$ & 1.21) & 1.16 & $(1.13$ & 1.19) \\
\hline & Alpha & 3.98 & $\left(\begin{array}{ll}3.86 & 4.11\end{array}\right)$ & 3.44 & $(3.33$ & $3.55)$ & 3.29 & $(3.19$ & $3.40)$ & 3.28 & (3.18 & 3.39) & 3.25 & $(3.15$ & 3.36) & 3.19 & $(3.09$ & $3.30)$ \\
\hline & Pseudo R2 & $0 \%$ & & $2.11 \%$ & & & $2.73 \%$ & & & $2.79 \%$ & & & $2.93 \%$ & & & $3.22 \%$ & & \\
\hline
\end{tabular}

$95 \%$ Confidence intervals; * significant at 5\%; ** significant at $1 \%$; Variables not significant in any model: divorced, female*divorced, female*married 
Figure 1. Average number of physician visits during the past 12 months by country. Individuals aged 50 and above.

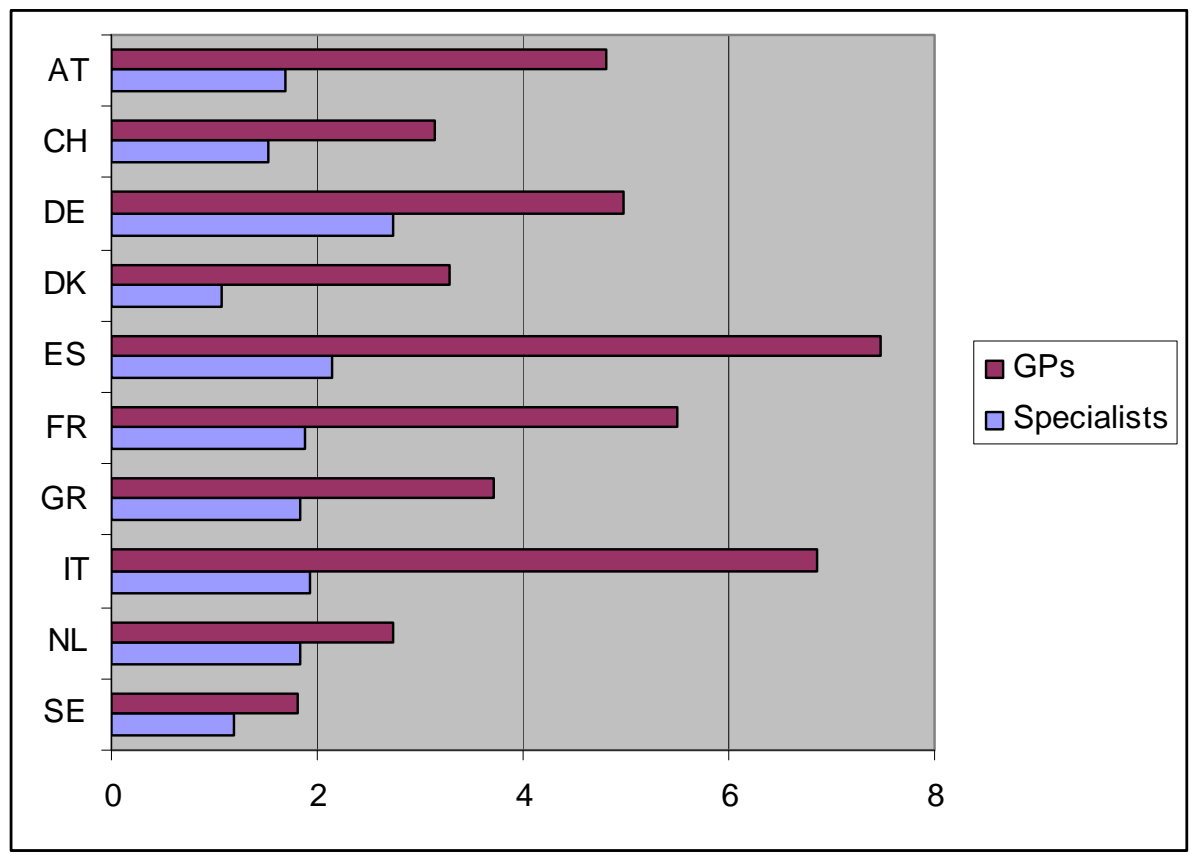


Figure 2: Amount of differences in total number of visits between countries expressed as the Mean Squared Error of the country mean residuals.

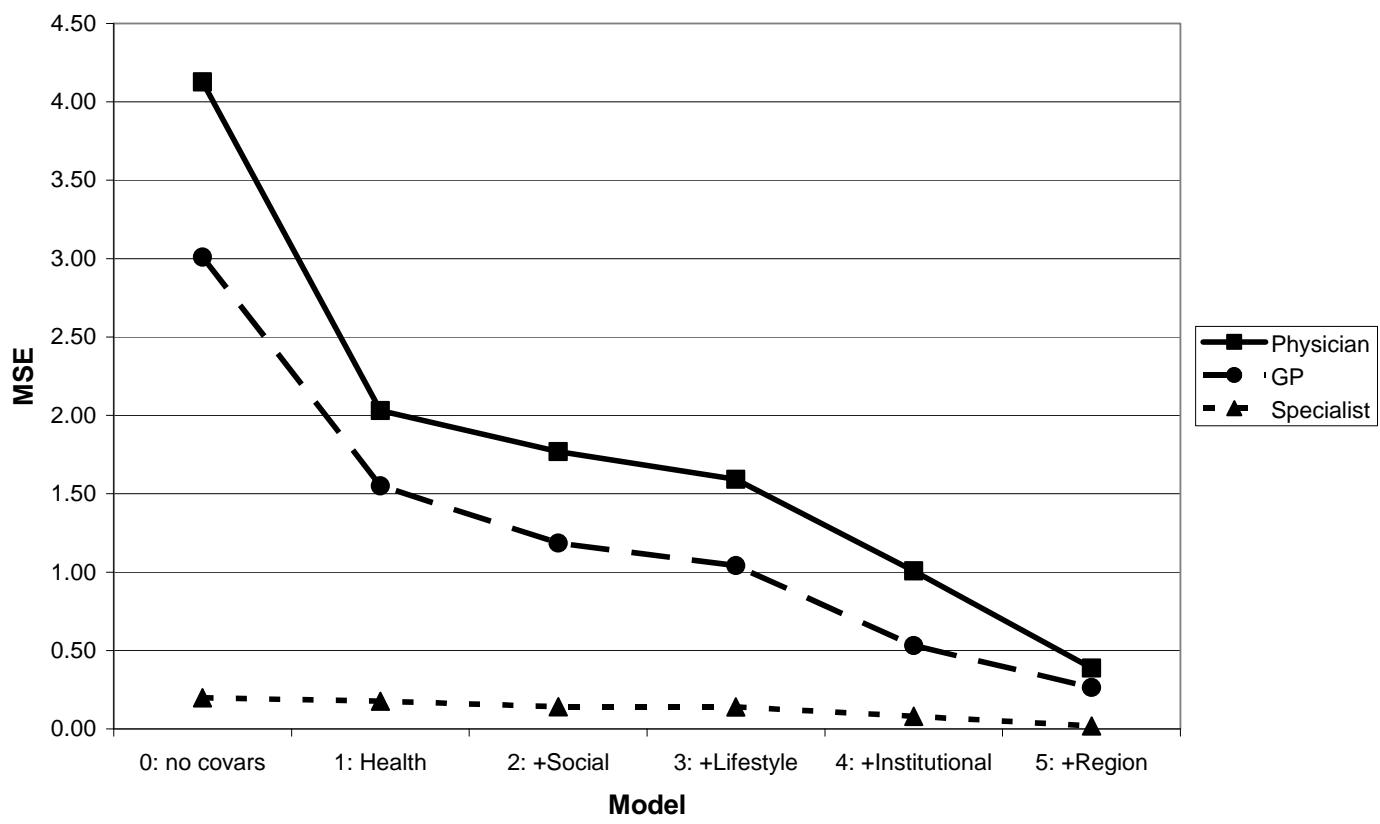

Figure 3: Explained portion of the differences in total number of visits between countries expressed as the relative Mean Squared Error of the country mean residuals.

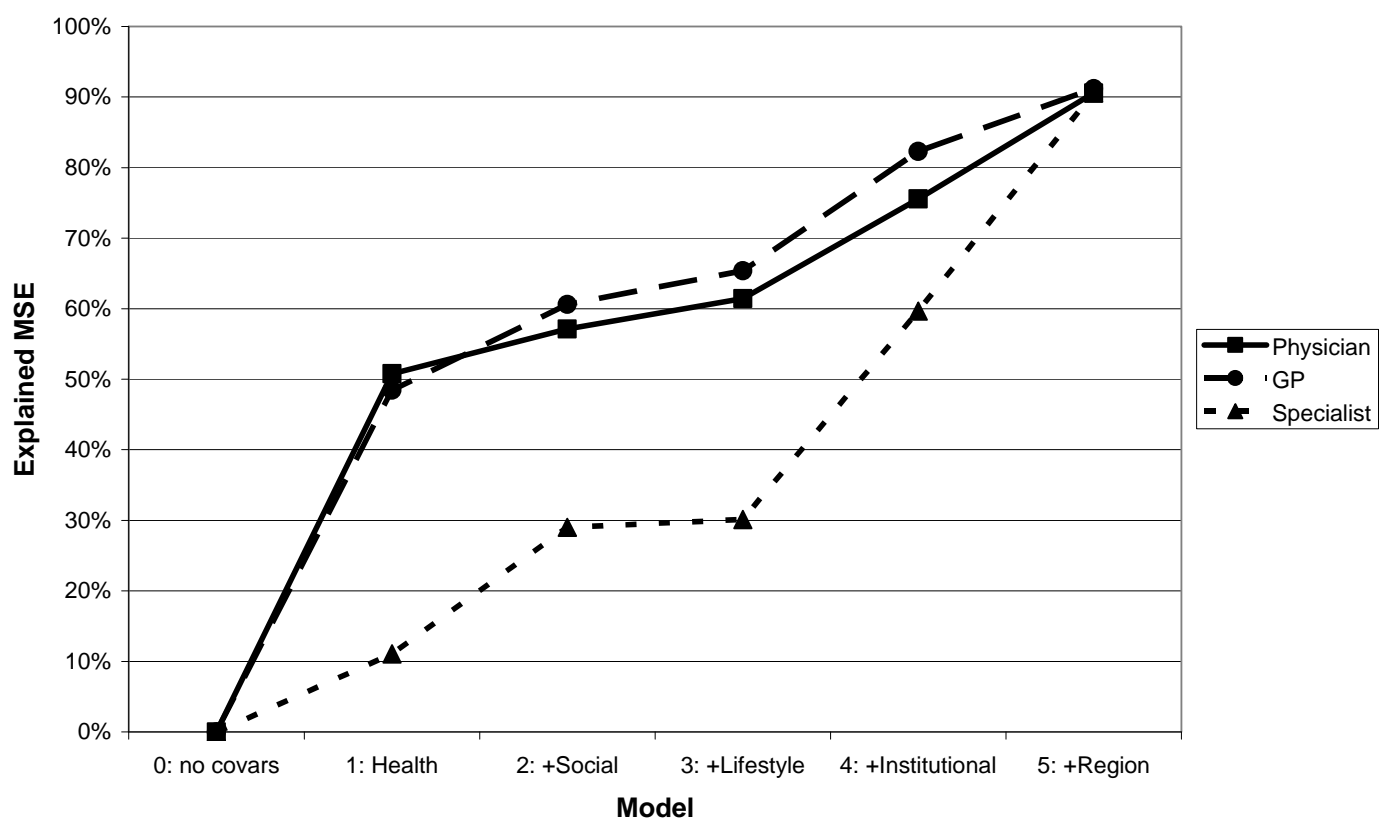


Figure 4: Mean country residual number of physician visits with 95\% bootstrap confidence intervals $(*=$ significantly different from the average level, $o=$ not sign.).
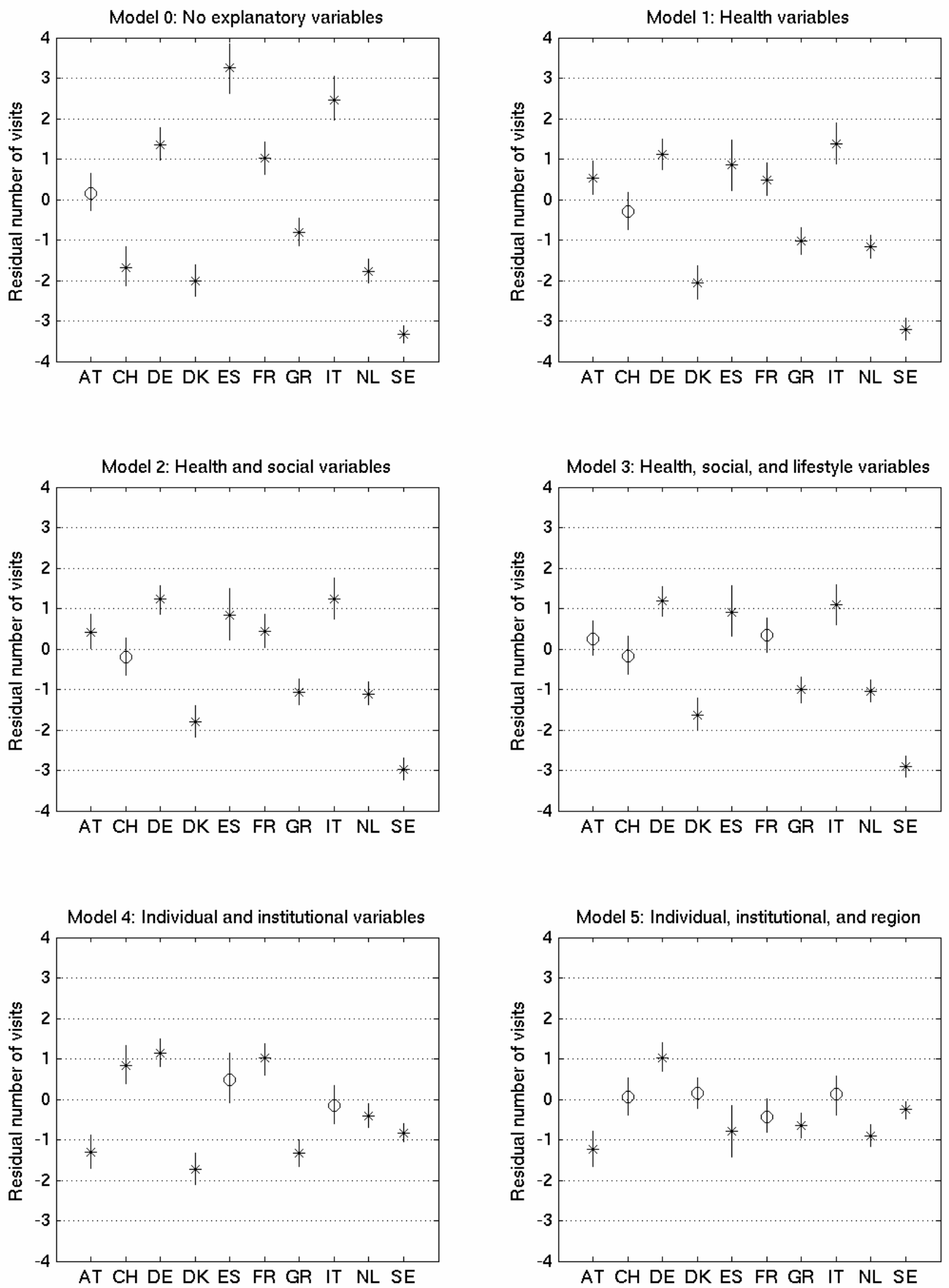
Figure 5: Mean country residual number of GP visits with 95\% bootstrap confidence intervals $(*=$ significantly different from the average level, o = not sign.).
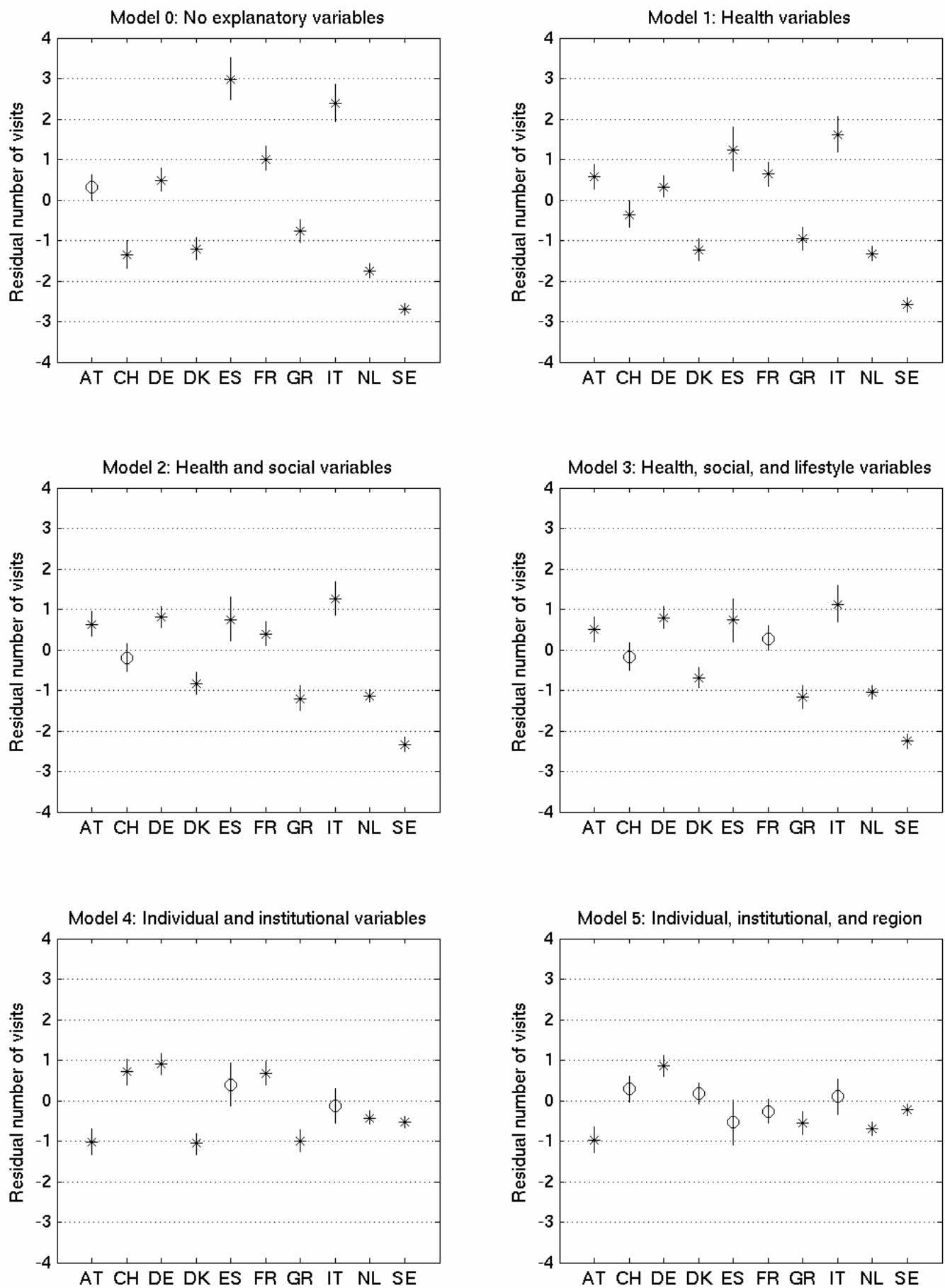
Figure 6: Mean country residual number of specialist visits with 95\% bootstrap confidence intervals $(*=$ significantly different from the average level, $o=$ not sign.).
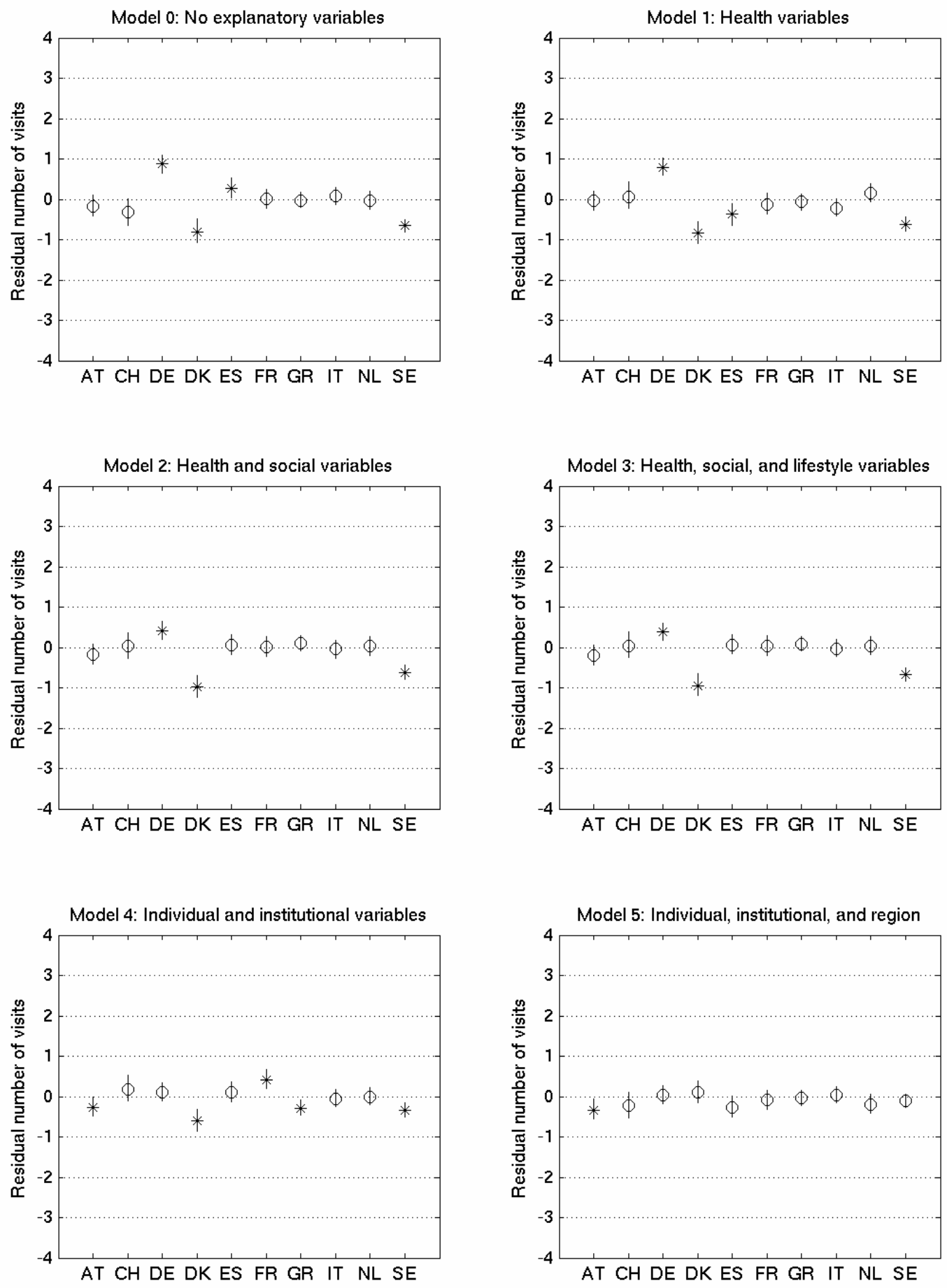